\title{
A (DES)NECESSIDADE DE REGULAMENTAÇÃO DA DISPENSA COLETIVA NO BRASIL: UMA ANÁLISE SOB A ÓTICA DO VALOR SOCIAL DO TRABALHO E DA DIGNIDADE DA PESSOA HUMANA
}

\section{THE NEED(LESSNESS) OF REGULATION ABOUT THE COLLECTIVE DISMISSAL IN BRAZIL: AN ANALYSIS UNDER THE PERSPECTIVE OF SOCIAL VALUE OF WORK AND HUMAN DIGNITY}

\author{
Nelma Karla Waideman Fukuoka \\ Mestranda no Programa de Pós-Graduação em Direito da Faculdade de Ciências Humanas e Sociais (UNESP). Franca, \\ SP, Brasil. \\ nelmawf@terra.com.br \\ VICTOR HUgo ALMEIDA \\ Doutor em Direito do Trabalho pela Faculdade de Direito da Universidade de São Paulo (USP). Docente vinculado ao \\ Programa de Pós-Graduação em Direito da Universidade Estadual Paulista "Júlio de Mesquita Filho" (UNESP). São \\ Paulo, SP, Brasil. \\ victorhugo.professor@gmail.com
}

\begin{abstract}
RESUMO
No cenário brasileiro atual, não é raro se noticiar a ocorrência de dispensas coletivas envolvendo um grande número de trabalhadores. As justificativas têm se baseado em fatores vinculados à situação econômica do país. Nesse contexto, o presente trabalho tem por objetivo examinar a dispensa coletiva arbitrária, sob o viés dos ditames da preservação de empregos insculpido na Constituição Federal de 1988 e dos princípios do valor social do trabalho e da dignidade humana. Como método de procedimento, adotou-se o levantamento de dados por meio da técnica de pesquisa bibliográfica. $E$, como método de abordagem, adotou-se o método dedutivo. Destaca-se, na atualidade, a imperativa necessidade de modernizar e atualizar o Direito do Trabalho face à realidade econômica, no sentido de enfrentar os grandes desafios próprios desse ramo do direito, dentre os quais a crise do emprego se afigura o mais complexo.
\end{abstract}

Palavras-chave: dignidade da pessoa humana; Direito do Trabalho; dispensa coletiva; valor social do trabalho.

\begin{abstract}
In the current Brazilian scenario, it is not uncommon to report the occurrence of collective dismissals involving a large number of workers. The justifications are based on factors linked to the economic situation of the country. In this context, this paper aims to examine the arbitrary collective dismissal, under the perspective of preservation of jobs inserted in the Federal Constitution of 1988 , as well as the principles of social value of work and human dignity. As a method of procedure, we adopted the data collection through the technique of literature research. As a method of approach, the deductive method was used. It stands out, nowadays, the imperative need to modernize and upgrade the labor laws in face of the economic reality, in a way to face the great challenges typical to this area of law, among which the employment crisis appears to be the most complex.
\end{abstract}

Keywords: human dignity; Labor Law; collective dismissal; social value of work. 

COLETIVA NO BRASIL: UMA ANÁLISE SOB A ÓTICA DO VALOR SOCIAL DO TRABALHO E DA DIGNIDADE DA PESSOA HUMANA

\section{SUMÁRIO}

INTRODUÇÃO; 1 CRISE ECONÔMICA E DISPENSA COLETIVA; 2 O VALOR SOCIAL DO TRABALHO E A EFETIVAÇÃO DO PRINCÍPIO DA DIGNIDADE HUMANA; 3 A DISPENSA COLETIVA NO CENÁRIO JUSLABORAL BRASILEIRO; 4 A (DES)NECESSIDADE DE REGULAMENTAÇÃO DA DISPENSA COLETIVA NO BRASIL; CONCLUSÃO; REFERÊNCIAS.

\section{INTRODUÇÃO}

No cenário brasileiro atual, não é raro se noticiar a ocorrência de dispensas coletivas envolvendo um grande número de trabalhadores. As justificativas têm se baseado em fatores vinculados à situação econômica da empresa, do setor ou da atividade em geral, bem como em decorrência de causas disciplinares, tecnológicas ou financeiras. Assim, o presente trabalho tem por objetivo examinar a dispensa coletiva arbitrária, sob o viés dos ditames da preservação de empregos e dos princípios do valor social do trabalho e da dignidade humana, insculpidos na Constituição Federal de 1988.

Como método de procedimento, adotou-se o levantamento de dados por meio da técnica de pesquisa bibliográfica em materiais já publicados (por exemplo, doutrinas, legislação, entendimentos jurisprudenciais, artigos, matérias publicadas em jornais/revistas, sítios eletrônicos, dissertações, entre outros). E, como método de abordagem, adotou-se o método dedutivo, buscando-se, a partir das premissas do valor social do trabalho e da dignidade da pessoa humana, examinar a (des)necessidade de regulamentação da dispensa coletiva e o papel da Justiça do Trabalho frente a esse fenômeno sociojurídico.

$\mathrm{Na}$ primeira parte do presente artigo, aborda-se a situação de permanência dos trabalhadores brasileiros à margem de qualquer garantia formal de emprego e sustento, visto inexistirem regras positivas que coíbam a dispensa em massa como artifício empresarial de diminuição de custos da produção, principalmente em tempos de crise ecônomica. 0 segundo tópico apresenta uma análise reflexiva a respeito da preservação de empregos, sob o viés da garantia dos princípios constitucionais do valor social do trabalho e da dignidade humana.

Elucidando-se através da terceira parte, é que deve ser identificado e compreendido o direito à garantia de emprego contra o despedimento arbitrário ou injusto, segundo o disposto no art. $7^{\circ}$, inciso I, da Constituição Federal de 1988. A partir desse dispositivo, elucida-se o tratamento dado às dispensas coletivas no Brasil até o presente momento. Por fim, no último 
A (DES)NECESSIDADE DE REGULAMENTAÇÃO DA DISPENSA COLETIVA NO BRASIL: UMA ANÁLISE SOB A ÓTICA DO VALOR SOCIAL DO TRABALHO E DA DIGNIDADE DA PESSOA HUMANA

NELMA KARLA WAIDEMAN FUKUOKA VICTOR HUGO ALMEIDA

tópico, são expostos os desafios do Direito do Trabalho face ao desemprego e da revisão de modelo brasileiro de relações de trabalho, sob o enfoque do Direito Coletivo, revelando ser marcante o clamor para que a imperatividade constitucional seja efetivamente garantida e aplicada.

\section{CRISE ECONÔMICA E DISPENSA COLETIVA}

O desemprego, como fenômeno coletivo que atualmente se mostra, é coetâneo da moderna economia capitalista, apresentando-se como fenômeno estrutural em razão da extrema divisão do trabalho, dos métodos de produção, da distribuição e da acumulação de renda. ${ }^{1}$ Através do uso da tecnologia e da exigência de trabalhadores extremamente qualificados, o modelo toyotista criou um exército de reserva, pronto para ocupar postos de trabalho, cada vez mais raros, elevando as taxas de desemprego no contexto global. ${ }^{2}$

Nas palavras de Enoque Ribeiro dos Santos:

É inegável que a globalização da economia e seus efeitos - abertura dos mercados, aumento da concorrência, maior fluidez financeira, transferência de propriedade, novas tecnologias, introdução de novos procedimentos eletrônicos e de informatização, diminuição das margens de benefícios concedidos aos empregados, alteração da política de pessoal - ocasionam maior descentralização das empresas e são responsáveis não apenas pelo recrudescimento do nível de desemprego na economia, como também por transformações profundas no mercado de trabalho. ${ }^{3}$

Neste contexto, é imperioso considerar os fatos políticos, econômicos e sociais decorrentes da globalização econômica, que têm imposto uma revisão crítica do processo judicial. Dentre eles, está a crise econômica de 2008/2009, que se originou da tendência do mercado financeiro de crescer além do que permitem os recursos da economia real, conforme evidencia Paul Singer:

Desde o seu início está o capitalismo sujeito a crises e, a partir do momento em que ele passou a dominar a economia de várias nações, estas crises adquiriram

\footnotetext{
${ }_{1}^{1}$ COSTA, Orlando Teixeira da. Direito coletivo do trabalho e crise econômica. São Paulo: LTr, 1991.

${ }^{2}$ GONÇAVES, Antônio Fabrício de Matos; KNEIPP, Bruno Burgarelli Albergaria. Reestruturação produtiva, globalização e neoliberalismo: reflexos o modelo brasileiro e suas consequências na legislação trabalhista. Revista do Advogado, São Paulo, n. 121, a. XXXIII, nov. 2013.

3 SANTOS, Enoque Ribeiro dos. Fundamentos do Direito Coletivo do Trabalho nos Estados Unidos da América, na União Europeia, no Mercosul e a Experiência Brasileira. Rio de Janeiro: Lumen Juris, 2006. p. 83.
} 
A (DES)NECESSIDADE DE REGULAMENTAÇ̃̃O DA DISPENSA COLETIVA NO BRASIL: UMA ANÁLISE SOB A ÓTICA DO VALOR SOCIAL DO TRABALHO E DA DIGNIDADE DA PESSOA HUMANA

caráter cíclico e passaram a desempenhar um papel decisivo no que se refere à compreensão crítica do funcionamento do sistema. ${ }^{4}$

Os riscos econômicos do empreendimento são do empregador, conforme o art. $2^{\circ}$ da Consolidação das Leis do Trabalho (CLT). Assim, sendo do empregador o risco do negócio, não se pode transferi-lo aos empregados, nem mesmo em épocas de turbulência. Tais riscos sequer podem afetar os direitos dos trabalhadores, embora possam influenciar a continuidade do contrato de trabalho, caso a empresa encerre suas atividades. ${ }^{5}$ Apesar disso, os órgãos midiáticos constantemente noticiam reações das empresas à crise através de demissões em massa, corte de custos, fechamento de estabelecimentos, dentre outras medidas extremas.

No entanto, o núcleo de uma crise global não repousa na fria análise mercadológica, mas sim num aprofundamento das desigualdades sociais, na equidistância da justiça social e no empobrecimento da classe trabalhadora ${ }^{6}$. Diante dessas inseguranças do mundo do trabalho, o desemprego se mostra como a ponta mais visível desse verdadeiro iceberg ${ }^{7}$, de acordo com Jorge Luiz Souto Maior:

0 problema do desemprego deve ser tratado com eficiência. Não se pode reduzilo a resultado de mera operação matemática: menor custo, menor desemprego, pois que isso representa um engodo, não elimina o problema e, por causa da precarização das relações de trabalho, gera outro problema, qual seja, o aumento do fosso (um verdadeiro abismo) entre ricos e pobres, aumentando a cada dia o número de pobres. ${ }^{8}$

É evidente que a estrutura atual não consegue absorver o desemprego com o necessário equilíbrio, já que a atual lógica global favorece o desemprego e a diminuição do rendimento daquele que ainda consegue trabalho. Numa análise qualitativa do desemprego, nota-se que os empregos mais bem remunerados se preservam para os segmentos já de renda mais alta, embora em dimensão insuficiente para permitir a contínua mobilidade socioprofissional. 0 resultado disso se apresenta no "aprofundamento da crise de reprodução social no interior do mercado de trabalho", conforme esclarece Ricardo Luiz Coltro Antunes:

\footnotetext{
${ }^{4}$ SINGER, Paul. Desenvolvimento e crise. São Paulo: DIFEL, 1968. p. 158.

${ }^{5}$ MARTINS, Sérgio Pinto. A continuidade do contrato de trabalho. São Paulo: Atlas, 2000.

${ }^{6}$ SOUTO MAIOR, Jorge Luiz. 0 direito do trabalho como instrumento de justiça social. São Paulo: LTr, 2000. p. 129-130.

7 MATTOSO, Jorge. Emprego e concorrência desregulada: incertezas e desafios. In: OLIVEIRA, C. E.; MATTOSO, J. E. L. (Orgs.). Crise e trabalho no Brasil: Modernidade ou volta ao passado? São Paulo: Scritta, 1996. p. 27.

${ }^{8}$ SOUTO MAIOR, Jorge Luiz. 0 direito do trabalho como instrumento de justiça social. São Paulo: LTr, 2000, p. 181.

${ }^{9}$ ANTUNES, Ricardo Luis Coltro. O continente do labor. São Paulo: Boitempo, 2011. p. 122.
} 
A (DES)NECESSIDADE DE REGULAMENTAÇ̃̃O DA DISPENSA COLETIVA NO BRASIL: UMA ANÁLISE SOB A ÓTICA DO VALOR SOCIAL DO TRABALHO E DA DIGNIDADE DA PESSOA HUMANA

É certo que a mencionada crise atingiu, em cheio, a regulação das relações individuais e coletivas de trabalho humano, propondo-lhe mutações, por vezes teratogênicas, em nome da "modernização" de seus fundamentos elementares e - quiçá - das premissas constitucionais vigentes, na medida em que atinge e afeta, violentamente, a proteção de direitos fundamentais constitucionais. ${ }^{10}$

Todavia, para Souto Maior, o consequente achatamento das garantias sociais não se dá em virtude de crise, pois os lucros do capital têm sido cada vez maiores, mas em virtude da concorrência internacional ${ }^{11}$. Por sua vez, a mudança na natureza do trabalho também está contribuindo para a insegurança econômica dos trabalhadores, uma vez que muitos deles já não conseguem encontrar empregos com jornada integral e duração indeterminada ${ }^{12}$. Disto pode-se concluir que o Direito do Trabalho acaba se tornando a seara jurídica mais suscetível às transformações decorrentes do processo de globalização ${ }^{13}$.

\section{VALOR SOCIAL DO TRABALHO E A EFETIVAÇÃO DO PRINCÍPIO DA DIGNIDADE HUMANA}

O trabalho é inerente ao ser humano e a ele está relacionado desde o início dos tempos. Por meio dele o ser humano se transforma e transforma o mundo. 0 trabalho, no entendimento de Enoque dos Santos Ribeiro, possui duas faces, como uma moeda: por um lado, geralmente, ele é um serviço ou uma atividade, prestado por um homem ou uma mulher em uma organização, uma empresa, ou ainda uma pessoa física; de outro lado, para a maioria dos indivíduos, ele é a principal fonte de renda. Graças a esta dupla natureza que o trabalho se diferencia dos bens e serviços colocados à disposição dos consumidores nos outros mercados, já que como fonte de renda ele desempenha um importante papel na distribuição do nível de vida no seio de uma coletividade. ${ }^{14}$

\footnotetext{
${ }^{10}$ BRANCO, Ana Paula Tauceda. A colisão dos princípios constitucionais no direito do trabalho. São Paulo: LTr, 2007. p. 19.

${ }^{11}$ SOUTO MAIOR, Jorge Luiz. O direito do trabalho como instrumento de justiça social. São Paulo: LTr, 2000.

${ }^{12}$ RIFKIN, Jeremy. O fim dos empregos: o declínio inevitável dos níveis dos empregos e a redução da força global de trabalho. São Paulo: Makron Books, 1995.

${ }^{13}$ GODOY, Arnaldo Moraes. Globalização e Direito: a mundialização do capital e seus efeitos no modelo normativo brasileiro. Argumentum Revista de Direito, Marília, v. 3. Disponível em: <http://www.unimar.br/biblioteca/publicacoes/pos/Direito_vol_03.pdf>. Acesso em: 16 ago. 2016.

${ }^{14}$ SANTOS, Enoque Ribeiro dos. O Direito do Trabalho e o desemprego. São Paulo: LTr, 1999.
} 
A (DES)NECESSIDADE DE REGULAMENTAÇÃO DA DISPENSA COLETIVA NO BRASIL: UMA ANÁLISE SOB A ÓTICA DO VALOR SOCIAL DO TRABALHO E DA DIGNIDADE DA PESSOA HUMANA

$\mathrm{Na}$ perspectiva do Direito, a atividade humana relativa ao trabalho incorpora, pelo menos, os cinco seguintes enfoques ou valores: econômico (é fonte de criação de renda e propicia o consumo de bens e serviços para a satisfação das necessidades humanas; fator ou elemento de custo da produção), jurídico (é um fator de criação de relação jurídica, fonte de direitos e obrigações entre o prestador e o tomador de serviços), político (é fator de crescimento da economia do Estado que o capacita a propiciar o bem-estar geral da coletividade), sociológico (é fator que propicia a maior intensidade de desenvolvimento, a expansão de contatos sociais e a inclusão social das classes trabalhadoras) e psicológico (fator trabalho é oportunidade de expansão e aperfeiçoamento da personalidade, fonte de projeção e afirmação social). ${ }^{15}$

A classe trabalhadora, embora tenha se beneficiado com as mudanças de visão do mundo ocasionadas pela ascensão do comércio e do capitalismo, acabou desses se tornando refém. Com as ameaças geradas pela crise, os meios que o trabalhador possui para a efetivação de seus direitos, como sindicatos, por exemplo, acabaram sendo enfraquecidos. ${ }^{16}$

Nessa seara, apesar de a Constituição Federal ${ }^{17}$ prever uma série de garantias a esta classe, os fatores políticos atrelados aos econômicos impedem que estes direitos sejam fielmente efetivados. Por vezes, o Direito do Trabalho é menosprezado pelos próprios juristas. Nesse quadro, vive o trabalhador brasileiro à beira da miséria pelos baixíssimos salários que recebe, trabalhando, quase sempre, em péssimas condições labor-ambientais.

Em muitas vezes, o emprego, além de representar a única fonte da sua própria subsistência e de sua família, representa, antes de tudo, a base de sua existência e da sua própria dignidade como pessoa humana. Nessa direção, pontua Ana Paula Tauceda Branco:

[...] não constitui o homem uma 'máquina', nem o trabalho unicamente uma 'mercadoria', ou, na acepção moral, cultural ou religiosa tão-somente um fardo, um encargo, um castigo, uma dívida, uma pena, mas antes e, sobretudo, um valor - dignificação do trabalho - que fundamenta os Direitos Fundamentais do Homem na sua formação cultural e que é sustentado por dois vieses concomitantes inerentes ao Direito e à Moral. ${ }^{18}$

\footnotetext{
${ }^{15}$ PANCOTTI, José Antônio. Aspectos jurídicos da dispensa coletiva no Brasil. Revista do Tribunal Regional do Trabalho da $15^{\text {a }}$ Região, Campinas, n. 35, p. 39-67, 2009.

${ }^{16}$ BRANCO, Ana Paula Tauceda. A colisão dos princípios constitucionais no direito do trabalho. São Paulo: LTr, 2007.

17 BRASIL. Constituição Federal. Brasília: Senado Federal, 1988. Disponível em: <http://www.planalto.gov.br/ccivil_03/constituicao/constituicaocompilado.htm>. Acesso em: 16 ago. 2016.

${ }^{18}$ BRANCO, Ana Paula Tauceda. A colisão dos princípios constitucionais no direito do trabalho. São Paulo: LTr, 2007, p. 61.
} 
A (DES)NECESSIDADE DE REGULAMENTAÇÃO DA DISPENSA COLETIVA NO BRASIL: UMA ANÁLISE SOB A ÓTICA DO VALOR SOCIAL DO TRABALHO E DA DIGNIDADE DA PESSOA HUMANA

A Teoria dos Direitos Fundamentais do Homem funda-se na premissa do mínimo necessário para que o ser humano possa viver com dignidade a ponto de desenvolver, nos ensaios da experiência da vida, sua essência e sua personalidade, não se ocupando somente com a subsistência desse ser humano, mas também com a sua realização plena através de cada conquista alcançada e de cada valor que passa, dinamicamente, a agregar a existência e a potencialidade humanas. ${ }^{19}$

A dignidade da pessoa humana é inerente a sua própria condição. Por isso, é indubitável que os ideais trabalho e dignidade humana são indissociáveis, sendo os direitos sociotrabalhistas uma parcela dos direitos fundamentais. E a dignidade do trabalhador, como ser humano, deve ter profunda ressonância na interpretação e aplicação das normas legais e das condições contratuais de trabalho, uma vez que o trabalho sem dignidade pode rebaixar o ser humano à condição análoga a de escravo ou até mesmo a de animal. Nessa perspectiva, ressalta Souto Maior a valorização do trabalho:

A valorização do trabalho é algo que torna possível a sobrevivência do próprio capital e, no fundo, a sobrevivência desse modelo de sociedade. Quanto menos o trabalho vale, mais as pessoas o desprezam. 0 trabalho é pena - a concepção vem dos gregos - e não prazer. 0 prazer advém dos benefícios que o trabalho nos proporciona - benefícios econômicos, já que vivemos num mundo capitalista. ${ }^{20}$

0 pressuposto da proteção social do trabalhador, frente à supremacia econômica do empregador, expressão da desigualdade jurídica, é uma forma de colocar em situação de relativa igualdade os dois polos da relação de trabalho. Para Maurício Godinho Delgado, o trabalho com garantias mínimas - que no mundo capitalista tem se confundido com o emprego, ao menos para os despossuídos de poder socioeconômico - torna-se, na prática, o grande instrumento de alcance no plano social da dignidade humana. ${ }^{21}$

Ao lado do direito à vida, a dignidade humana constitui o núcleo essencial dos direitos humanos, fundamentando e conferindo unidade não apenas aos direitos fundamentais, mas, também, à organização econômica. Trata-se de um primado claramente evidenciado no sistema da Constituição Federal de 1988, no qual a dignidade da pessoa humana é adotada em dois

\footnotetext{
${ }_{19}$ BRANCO, Ana Paula Tauceda. A colisão dos princípios constitucionais no direito do trabalho. São Paulo: LTr, 2007, p. 61.

${ }^{20}$ SOUTO MAIOR, Jorge Luiz. 0 direito do trabalho como instrumento de justiça social. São Paulo: LTr, 2000 , p. 187.

${ }^{21}$ DELGADO, Maurício Godinho. Curso de direito do trabalho. 10. ed. São Paulo: LTr, 2011.
} 
A (DES)NECESSIDADE DE REGULAMENTAÇÃO DA DISPENSA COLETIVA NO BRASIL: UMA ANÁLISE SOB A ÓTICA DO VALOR SOCIAL DO TRABALHO E DA DIGNIDADE DA PESSOA HUMANA

momentos: como fundamento da República Federativa do Brasil (art. $1^{\circ}$, III) e como fim da ordem econômica (art. 170, caput) ${ }^{22}$, conforme expõe Eros Grau:

A dignidade da pessoa humana comparece, assim, na Constituição de 1988, duplamente: no art. $1^{\circ}$ como princípio político constitucionalmente conformador (Canotilho); no art 170, caput, como princípio constitucional impositivo (Canotilho) ou diretriz (Dworkin) - ou, ainda, direi eu, como norma-objetivo. Nesta sua segunda consagração constitucional, a dignidade da pessoa humana assume a mais pronunciada relevância, visto comprometer todo o exercício da atividade econômica, em sentido amplo - e em especial, o exercício da atividade econômica em sentido estrito - com o programa de promoção da existência digna, de que, repito, todos devem gozar. Daí porque se encontram constitucionalmente empenhados na realização desse programa - dessa política pública maior - tanto o setor público quanto o setor privado. Logo, o exercício de qualquer parcela da atividade econômica de modo não adequado àquela promoção expressará violação do princípio duplamente contemplado na Constituição. ${ }^{23}$

Nesse sentido, ainda:

Partindo da premissa de que uma das funções dos Princípios Constitucionais Fundamentais é orientar, vasta e adequadamente, a interpretação e a aplicação das normas jurídicas, há que ser vencida essa dificuldade de assimilar uma postura hermenêutica tendente a reconstruir, nos casos concretos, uma unidade textual da Carta Constitucional capaz de sustentar, em todos os níveis, o trabalho humano como valor social a ser respeitado pelo Estado e por particulares nas mais diversas dimensões de suas atividades sociais, reconhecendo-lhes sentido, importância e reverência como natural faceta do Princípio Constitucional vetorial que é o da Dignidade da Pessoa Humana. ${ }^{24}$

A Constituição Federal de 1988, complementando o art. 170, caput, ainda reafirma a supremacia do valor social do trabalho evidenciado como fundamento da República Federativa do Brasil, conforme dispõe o art. $1^{\circ}$, inciso IV, da Lei Maior. Segundo Eros Grau, a interação entre esses dois princípios e os demais por ela contemplados - particularmente o que define como fim da ordem econômica (mundo do ser) assegurar a todos existência digna - resulta que valorizar o trabalho humano e tomar como fundamental o valor social do trabalho acarreta um tratamento peculiar ao trabalho e seus agentes (os trabalhadores) tratamento peculiar. ${ }^{25}$

\footnotetext{
${ }^{22}$ GRAU, Eros Roberto. A ordem econômica na Constituição de 1988. 13. ed. São Paulo: Malheiros Editores, 2008.

${ }^{23}$ GRAU, Eros Roberto. A ordem econômica na Constituição de 1988. 13. ed. São Paulo: Malheiros Editores, 2008, p. 198-199.

${ }^{24}$ BRANCO, Ana Paula Tauceda. A colisão dos princípios constitucionais no direito do trabalho. São Paulo: LTr, 2007, p. 62.

${ }^{25}$ GRAU, Eros Roberto. A ordem econômica na Constituição de 1988. 13. ed. São Paulo: Malheiros Editores, 2008.
} 
A (DES)NECESSIDADE DE REGULAMENTAÇ̃̃O DA DISPENSA COLETIVA NO BRASIL: UMA ANÁLISE SOB A ÓTICA DO VALOR SOCIAL DO TRABALHO E DA DIGNIDADE DA PESSOA HUMANA

O Princípio do Valor Social do Trabalho não constitui tão-somente uma regra juridicamente ordenada, mas antes um "cordão umbilical" em que o Sistema é realimentado pelo Princípio Constitucional Fundamental da Dignidade da Pessoa Humana que, a nosso ver, inegavelmente, ocupa local e função (informadora, normativa e interpretadora) em primazia às demais normas, vinculando-as posicionamentos hermenêuticos que reconheçam a pessoa humana, especialmente na figura do trabalhador e do seu trabalho, como pilar estruturante do Sistema. ${ }^{26}$

Note-se que o referido valor, previsto como princípio constitucional pelo ordenamento jurídico pátrio, vem expresso não somente no título referente aos Princípios Fundamentais da República, mas também no título relativo à Ordem Econômica e Financeira ${ }^{27}$, afirmando estar a ordem econômica fundada na valorização do trabalho humano. Diante disso, esclarece José Afonso da Silva:

Não é fácil estremar, com nitidez, os direitos sociais dos direitos econômicos. [...] em verdade, o trabalho é um componente das relações de produção e, nesse sentido, tem dimensão econômica indiscutível. A Constituição tomou partido a esse propósito, ao incluir os direitos dos trabalhadores como espécie dos direitos sociais, e o trabalho como primado básico da ordem social (art. $7^{\circ}$ e 193). É a posição correta. ${ }^{28}$

O inciso VIII do art. 170 estabelece o princípio da busca do pleno emprego, já previsto desde a Declaração Universal dos Direitos do Homem, conforme se extrai do parágrafo $1^{\circ}$ do art. XXIII: “todo homem tem direito ao trabalho, à livre escolha de emprego, a condições justas e favoráveis de trabalho e à proteção contra o desemprego"29.

Em regra, tal princípio apenas é mencionado como um mero desdobramento do princípio constitucional fundamental do valor social do trabalho ${ }^{30}$. Contudo, como afirma Tavares, a busca do pleno emprego, juntamente com a justiça social, deve servir de base para a interpretação de todos os direitos trabalhistas contidos na Constituição de $1988^{31}$. Ademais:

Independentemente de se entender o rol indicado pelo art. 170 da Constituição como contemplativo todo ele de princípios, é certo que nele se albergam, por

\footnotetext{
${ }^{26}$ BRANCO, Ana Paula Tauceda. A colisão dos princípios constitucionais no direito do trabalho. São Paulo: LTr, 2007, p. 62.

27 BRANCO, Ana Paula Tauceda. A colisão dos princípios constitucionais no direito do trabalho. São Paulo: LTr, 2007, p. 62.

${ }^{28}$ SILVA, José Afonso da. Curso de direito constitucional positivo. 35. ed. São Paulo: Malheiros, 2011. p. 286.

29 ONU. Declaração Universal dos Direitos Humanos. 1948. Disponível em: <http://unesdoc.unesco.org/images/0013/001394/139423por.pdf>. Acesso em: 16 ago. 2016.

${ }^{30}$ BRANCO, Ana Paula Tauceda. A colisão dos princípios constitucionais no direito do trabalho. São Paulo: LTr, 2007.

${ }^{31}$ TAVARES, André Ramos. Direito Constitucional Econômico. 2. ed. São Paulo: Editora Método. 2006.
} 
expressa menção constitucional, não apenas os fundamentos da ordem econômica, mas igualmente finalidades, ou seja, os objetivos a serem atingidos por meio da implementação de seus ditames econômicos. [...] Assim, o objetivo a ser buscado, consoante a Constituição, é dúplice, englobando a procura de uma existência digna e consoante os ditames da justiça social. ${ }^{32}$

Para a Organização Internacional do Trabalho (OIT), o pleno emprego é fundamental para a erradicação da pobreza e da fome. A população teria direito ao pleno emprego e caberia à sociedade estabelecer leis e normas que possibilitassem a utilização integral da oferta de trabalho, já que o pleno emprego é uma condição necessária para a restauração da dignidade dos trabalhadores e uma condição essencial para a estabilidade e o progresso da sociedade ${ }^{33}$. E, ainda:

\begin{abstract}
A busca do pleno emprego é um princípio diretivo da economia que se opõe às políticas recessivas. Pleno emprego é expressão abrangente da utilização, ao máximo grau, de todos os recursos produtivos. Mas aparece, no art. 170, VIII, especialmente no sentido de propiciar trabalho a todos quantos estejam em condições de exercer uma atividade produtiva. Trata-se do pleno emprego da força de trabalho capaz. Ela se harmoniza, assim, com a regra de que a ordem econômica se funda na valorização do trabalho humano. Isso impede que o princípio seja considerado apenas como mera busca quantitativa, em que a economia absorva a força de trabalho disponível, como o consumo absorve mercadorias. ${ }^{34}$
\end{abstract}

Ainda, numa clara opção de legitimar o valor social do trabalho, o constituinte institui, incansavelmente, o primado do trabalho humano sob um prisma categórico, também como base da Ordem Social, cujo preceito está insculpido no art. 193 da Constituição Federal. O valor social do trabalho, como um dos princípios constitucionais que fundamentam nossa República, há de ser experimentado pela pessoa humana tanto no âmbito da sociedade como no da economia, numa exploração de conteúdos que requerem a necessidade de conjugar uma relação de complementaridade e tensão entre os aspectos de direito e de dever do trabalho humano. ${ }^{35}$

De tal modo, abarca em si tanto a dimensão do direito a manter uma vida humana por meio da sobrevivência oportunizada por esse mesmo trabalho, como também a dimensão de

\footnotetext{
${ }^{32}$ TAVARES, André Ramos. Direito Constitucional Econômico. 2. ed. São Paulo: Editora Método. 2006, p. 128-129.

${ }^{33}$ KON, Anita. Pleno emprego no Brasil: interpretando os conceitos e indicadores. Revista Economia e Tecnologia (RET), v. 8, n. 2, p. 5-22, abr./jun. 2012. Disponível em: <http://www.economiaetecnologia.ufpr.br/revista/Volume\%208\%20n\%202/05\%20Anita\%20Kon.pdf>. Acesso em: 16 ago. 2016.

${ }^{34}$ SILVA, José Afonso da. Curso de direito constitucional positivo. 35. ed. São Paulo: Malheiros, 2011, p. 799.

35 BRANCO, Ana Paula Tauceda. A colisão dos princípios constitucionais no direito do trabalho. São Paulo: LTr, 2007.
} 
A (DES)NECESSIDADE DE REGULAMENTAÇ̃̃O DA DISPENSA COLETIVA NO BRASIL: UMA ANÁLISE SOB A ÓTICA DO VALOR SOCIAL DO TRABALHO E DA DIGNIDADE DA PESSOA HUMANA

NELMA KARLA WAIDEMAN FUKUOKA VICTOR HUGO ALMEIDA

dever, uma vez que a sociedade necessita da contribuição de todos para o seu adequado funcionamento e para a harmonização social. ${ }^{36}$ Nas palavras de Manoel Gonçalves Ferreira Filho:

Na verdade, o trabalho é ao mesmo tempo um direito e uma obrigação de cada indivíduo. Como direito, deflui diretamente do direito à vida. Para viver, tem o homem de trabalhar. A ordem econômica que the rejeitar o trabalho, the recusa o direito a sobreviver. Como obrigação, deriva do fato de viver o homem em sociedade, de tal sorte que o todo depende da colaboração de cada um. ${ }^{37}$

Se os direitos sociotrabalhistas constituem autênticos direitos fundamentais da pessoa humana do ordenamento jurídico, é exatamente nessa espécie de direitos que nosso Estado encontra sua própria razão de ser, motivo pelo qual se deve, a respeito deles, ser defendida sua inquestionável efetividade ${ }^{38}$. No entanto, há de se observar que:

Um equívoco hermenêutico vem sendo, constantemente, cometido, qual seja: atrelar o valor do trabalho humano às possibilidades econômicas e não em correspondência às necessidades humanas. [...] Ao contrário, esse mesmo hermeneuta é chamado a ficar atento a dois princípios fundamentais fixados pela Constituição da República: a Dignidade da Pessoa Humana e o valor social do trabalho, para que, de fato, a Ordem Econômica fundada na valorização social do trabalho humano possa realmente buscar o Pleno Emprego. ${ }^{39}$

Destarte, há de se visualizar as potencialidades transformadoras que são trazidas com as cláusulas principiológicas constitucionais da valorização do trabalho humano e do reconhecimento do valor social do trabalho ${ }^{40}$, as quais se mostram como um dos alicerces para a efetiva garantia da dignidade humana. Ou seja, a pergunta que se lança consiste na prevalência da Constituição, com a força de seus dispositivos em prol da dignidade da pessoa humana, ou da lex mercatoria, que converte tudo e todos em instrumento para a riqueza de poucos ${ }^{41}$. É esse o dilema dos velhos e, ainda, dos novos tempos.

\footnotetext{
${ }^{36}$ BRANCO, Ana Paula Tauceda. A colisão dos princípios constitucionais no direito do trabalho. São Paulo: LTr, 2007.

37 FERREIRA FILHO, Manoel Gonçalves. Curso de direito constitucional. 36. ed. rev. e atual. São Paulo: Saraiva, 2010. p. 387.

${ }^{38}$ BRANCO, Ana Paula Tauceda. A colisão dos princípios constitucionais no direito do trabalho. São Paulo: LTr, 2007.

${ }^{39}$ BRANCO, Ana Paula Tauceda. A colisão dos princípios constitucionais no direito do trabalho. São Paulo: LTr, 2007, p. 64.

40 GRAU, Eros Roberto. A ordem econômica na Constituição de 1988. 13. ed. São Paulo: Malheiros Editores, 2008.

${ }^{41}$ MINISTÉRIO PÚBLICO DO TRABALHO EM MINAS GERAIS. Terceirização versus proteção constitucional. Disponível em: <http://www.prt3.mpt.mp.br/informe-se/noticias-do-mpt-mg/254-terceirizacao-versusprotecao-constitucional>. Acesso em: 16 ago. 2016.
} 


\section{A DISPENSA COLETIVA NO CENÁRIO JUSLABORAL BRASILEIRO}

A partir de 1988, o direito à garantia do pleno emprego passou a ser previsto no art. $7^{\circ}$ da Constituição, cuja norma estabeleceu ser direito dos trabalhadores urbanos e rurais a relação de emprego protegida contra a despedida arbitrária ou sem justa causa, nos termos de lei complementar, que preverá indenização compensatória, dentre outros direitos.

Pela atual ausência da lei complementar trazida pela norma, o empregador tem, então, um direito potestativo de dispensar o empregado, ao qual este não pode se opor, salvo as exceções contidas na lei e desde que arque com as reparações econômicas pertinentes. Em regra, terá o empregado direito a aviso-prévio, $13^{\circ}$ salário proporcional, férias vencidas e proporcionais, saldo de salários, saque do FGTS, indenização de $40 \%$ e direito ao segurodesemprego. Tendo o empregado mais de um ano de prestação laboral para o mesmo empregador, haverá necessidade, também, de assistência perante o sindicato ou a Delegacia Regional do Trabalho ( $\$ 1^{\circ}$ do art. 477 da CLT). ${ }^{42}$

No Brasil, as empresas praticam dispensas coletivas imotivadas à semelhança das individuais. Isto é, demitem por simples manifestação unilateral e potestativa de vontade ${ }^{43}$. 0 espectro protetor do Direito do Trabalho em caso de dispensa coletiva é, no entanto, mais amplo em comparação com as dispensas individuais ${ }^{44}$, conforme atesta José Antônio Pancotti:

Esta afirmação sustenta-se nos fundamentos do Estado Democrático de Direito preconizados na Constituição da República [...]. Neste espectro de princípios basilares explícitos na Constituição da República encontram-se os fundamentos para sustentar que as dispensas coletivas de trabalhadores por empresas - sejam por inovações tecnológicas, automações, crises econômicas etc., ou por suspensão de estabelecimentos - não são imunes a uma rede de proteção de trabalhadores atingidos, em razão de seus impactos econômicos e sociais. Esta proteção deve ter outros parâmetros além daqueles que o Direito do Trabalho expressamente concede aos trabalhadores que sofrem demissões individuais. ${ }^{45}$

0 ordenamento jurídico brasileiro, portanto, ainda carece de regulamentação satisfatória e específica de tal fenômeno desde pelo menos a vigência da atual Constituição, conforme elucida Mário Gonçalves Júnior:

\footnotetext{
${ }^{42}$ MARTINS, Sérgio Pinto. Direito do Trabalho. 28. ed. São Paulo: Atlas, 2012.

${ }^{43}$ PANCOTTI, José Antônio. Aspectos jurídicos da dispensa coletiva no Brasil. Revista do Tribunal Regional do Trabalho da $15^{\text {a }}$ Região, Campinas, n. 35, p. 39-67, 2009.

${ }^{44}$ PANCOTTI, José Antônio. Aspectos jurídicos da dispensa coletiva no Brasil. Revista do Tribunal Regional do Trabalho da 15a Região, Campinas, n. 35, p. 39-67, 2009.

${ }^{45}$ PANCOTTI, José Antônio. Aspectos jurídicos da dispensa coletiva no Brasil. Revista do Tribunal Regional do Trabalho da 15a Região, Campinas, n. 35, p. 57-58, 2009.
} 
A (DES)NECESSIDADE DE REGULAMENTAÇÃO DA DISPENSA COLETIVA NO BRASIL: UMA ANÁLISE SOB A ÓTICA DO VALOR SOCIAL DO TRABALHO E DA DIGNIDADE DA PESSOA HUMANA

NELMA KARLA WAIDEMAN FUKUOKA VICTOR HUGO ALMEIDA

[...] na própria Carta de 1988, quando revogado completamente o regime da estabilidade decenal, o legislador constituinte convidou explicitamente o Congresso Nacional a regulamentar outras medidas contra a dispensa arbitrária. A multa sobre os depósitos do FGTS era para ser um contraponto às demissões individuais ou plúrimas (artigo $7^{\circ}$., I, CF), aplicáveis às demissões como um todo (inclusive as coletivas) somente enquanto a proteção contra a dispensa arbitrária não viesse (daí porque o percentual de $40 \%$ tem sede o art. 10, I, do Ato das Disposições Constitucionais Transitórias). Passadas quase duas décadas de vigência constitucional, infelizmente não há negar que tornamos definitiva uma garantia que literalmente deveria ter sido passageira (a multa do FGTS). Acomodamo-nos preguiçosamente sob um remendo constitucional. ${ }^{46}$

Em decorrência disso, a presidente Dilma Rousseff editou, em 6 de julho, a Medida Provisória n 680/2015, que criou o Plano de Proteção ao Emprego (PPE) e, em 19 de novembro, sancionou a Lei $n^{\circ} 13.189 / 2015$, que o instituiu em definitivo no país. O PPE permite a redução da jornada de trabalho em até 30\% de empresas que estejam enfrentando dificuldades financeiras, com diminuição proporcional nos rendimentos dos trabalhadores participantes do programa. Em contrapartida, 50\% da perda salarial desses empregados é ressarcida com recursos do Fundo de Amparo ao Trabalhador, sendo que o limite para essa compensação é de $65 \%$ do valor do maior benefício do Seguro Desemprego.

Pelo Plano, apenas as empresas integrantes ficam proibidas de dispensar arbitrariamente, ou sem justa causa, os empregados que tiverem sua jornada de trabalho temporariamente reduzida, mas somente enquanto vigorar a inscrição no programa e, após seu término, durante o prazo equivalente a um terço do período de adesão. Para Nelson Mannrich:

O programa é tímido, pois o Governo está mais preocupado com quanto vai ganhar ou perder. É tímido, ainda, se examinados outros instrumentos já em vigor [...]. A própria Constituição, no art. $7^{\circ}$, autoriza redução salarial, mediante negociação coletiva. Porque não os aperfeiçoar? No fundo, a preocupação maior do Governo é com a corrida ao seguro-desemprego, com prejuízos ainda maiores ao já combalido sistema. Em um Estado democrático de direito, preocupado com graves questões sociais como o desemprego, haveria mais espaço para debelar os efeitos deletérios da crise econômica, agindo de forma mais abrangente e enérgica. Basta ver a experiência de outros países, em situações como essas [...]. Como se vê, no lugar da timidez e da excessiva burocracia, poderia o Governo ter mais criatividade e de fato proteger o emprego contra a grave crise que assola nosso país. ${ }^{47}$

\footnotetext{
${ }^{46}$ GONÇALVES JÚNIOR, Mário. Demissão coletiva. Academia Brasileira de Direito, 3 jan. 2007. Disponível em: <http://www.abdir.com.br/doutrina/ver.asp?art_id=869\&categoria=Lei\%20Pel\%C3\%83\%C2\%A9>. Acesso em: 16 ago. 2016.

${ }^{47}$ MANNRICH, Nelson. Programa de Proteção ao Emprego (PPE): timidez e burocracia. Jota, São Paulo, 6 ago. 2015. Disponível em: <http://jota.uol.com.br/programa-de-protecao-ao-emprego-ppe-timidez-eburocracia>. Acesso em: 18 jul. 2016.
} 
A ausência de legislação acerca do tema da dispensa arbitrária coletiva - já delicado por sua natureza econômica e social - o torna ainda mais complexo, trazendo inúmeras questões de difícil equacionamento. A primeira delas refere-se ao próprio conceito de dispensa coletiva. ${ }^{48}$

De modo geral, é aquela fundada em razões exteriores à relação laboral, sendo decorrentes de motivos estruturais, tecnológicos ou conjunturais. Disso decorre que, ao contrário do que se pensa, a dispensa coletiva não é forma de dispensa individual plúrima, porque nesta, para cada demitido, pode haver causa diferente e normalmente tem o propósito de substituição do demitido por outro empregado. Na dispensa coletiva, a causa é única e o propósito é a redução do quadro de pessoal da empresa. ${ }^{49}$

Outra questão diz respeito ao procedimento da negociação e ao conteúdo do ajuste coletivo propriamente dito, que abrangem os critérios fixados para a dispensa, de maneira a proibi-la ou a determinar certas providências para sua apuração. Em diversas publicações sobre o assunto, não se é discutida a impossibilidade da dispensa, apenas se busca um meio de evitar a demissão de mais funcionários que o necessário ${ }^{50}$. Muitos também sustentam que, pelo fato de não existir norma expressa a limite, a dispensa coletiva poderia ocorrer "livremente", pois o julgador estaria restrito a decidir nos limites da lei (e lei não existiria) ${ }^{51}$. Mas, para Orlando Gomes:

A reorganização da empresa que implique diminuição de seus efetivos deve ser submetida a controle da autoridade administrativa.

A interessada tem de comunicar, com certa antecedência, o seu projeto de reorganização, informando o número de empregados, com as respectivas qualificações, que sobrarão e a data provável da dispensa coletiva. Não importa

\footnotetext{
${ }^{48}$ FELTRE, Andrezza Nazareth. Negociação coletiva como pressuposto para a dispensa em massa. 2012. 101 f. Dissertação (Mestrado) - FUMEC, Programa de Pós-Graduação em Direito, Belo Horizonte. Disponível em:

<http://www.fumec.br/anexos/cursos/mestrado/dissertacoes/completa/andrezza_nazareth_feltre.pdf> Acesso em: 16 ago. 2016.

${ }^{49}$ PANCOTTI, José Antônio. Aspectos jurídicos da dispensa coletiva no Brasil. Revista do Tribunal Regional do Trabalho da 15 ${ }^{\text {a }}$ Região, Campinas, n. 35, p. 39-67, 2009.

${ }^{50}$ FELTRE, Andrezza Nazareth. Negociação coletiva como pressuposto para a dispensa em massa. 2012. 101 f. Dissertação (Mestrado) - FUMEC, Programa de Pós-Graduação em Direito, Belo Horizonte. Disponível em:

<http://www.fumec.br/anexos/cursos/mestrado/dissertacoes/completa/andrezza_nazareth_feltre.pdf> Acesso em: 16 ago. 2016.

${ }^{51}$ TEODORO, Maria Cecília Máximo; SILVA, Aarão Miranda da. A imprescindibilidade da negociação coletiva nas demissões em massa e a limitação de conteúdo constitucionalmente imposta. Âmbito Jurídico, Rio Grande, XII, n. 64, maio 2009. Disponível em: <http://www.ambitojuridico.com.br/site/index.php?n_link=revista_artigos_leitura\&tartigo_id=6082>. Acesso em: 16 ago. 2016.
} 

COLETIVA NO BRASIL: UMA ANÁLISE SOB A ÓTICA DO VALOR SOCIAL DO TRABALHO E DA DIGNIDADE DA PESSOA HUMANA

que a redução do pessoal decorra de uma reestruturação da empresa ou de fusão de duas sociedades ou incorporação d'uma por outra.

No processamento da dispensa coletiva, a ser autorizada, devem ser levados em conta:

a) os fatores econômicos peculiares à empresa;

b) a situação geral de emprego no ramo de atividade e na região interessada.

Justifica-se a redução do pessoal se a reestruturação é economicamente necessária ou propícia à preservação ou à expansão da empresa, desde que a situação geral do emprego permita a pronta reabsorção dos empregados dispensados. Na França, o órgão administrativo de controle pode opor-se a despedidas em massa suscetíveis de causar grave perturbação na vida econômica de uma localidade, ou distúrbios sociais.

A intervenção estatal tem sido preconizada até o extremo de pretender-se que dependa de sua aprovação qualquer reestruturação de empresa que implique despedida coletiva e em convenções coletivas de trabalho têm sido introduzidas cláusulas que estipulam a proibição de despedir antes de esgotadas outras possibilidades de evitar a dispensa coletiva, como, por exemplo, a redução do horário de trabalho. Contrabalança-se a oposição estatal assegurando-se ao empresário uma indenização em ressarcimento do prejuízo que, nesse caso, sofre em proveito da coletividade, justificando-se esse seu direito na socialização da reparação das conseqüências danosas da ação administrativa.

É de se exigir, quando menos, uma comunicação à autoridade administrativa do trabalho para pô-la de sobreaviso, não somente para que tome as providências quanto ao desemprego dos futuros dispensados, proporcionando-lhes, se for o caso, subsídios ou encaminhando-os a outros empregos, mas também para fazer sentir aos trabalhadores que serão dispensados a presença do Estado e seu interesse em obviar as respectivas situações de desemprego. ${ }^{52}$

O debate jurídico é, assim, tomado pelo debate econômico e com este se confunde. Isto porque o desemprego é um problema, também, da ciência do Direito e não simplesmente da Economia, motivo pelo qual a atividade hermenêutica constitucional é responsável por criar elos entre o espectro da lei e o das aspirações e das necessidades sociais ${ }^{53}$, conforme elucida Ana Paula Tauceda Branco:

Desvelada a tendência predominante entre os intérpretes e os aplicadores do Direito Constitucional do Trabalho com relação a tal norma jurídica, dada à sua redação talvez pouco apropriada, no aspecto hermenêutico constitucional, tudo impele a que se entabule uma interpretação não mais subserviente somente aos interesses econômicos que tanto valorizam a suposta ineficácia e a inefetividade de normas relativas aos direitos fundamentais sociotrabalhistas, mas, ao contrário, ousa firmar uma interpretação que, reconhecendo a indubitável força normativa da Carta Constitucional, seja inspirada na conjugação do Princípio Constitucional da Dignidade da Pessoa Humana e o Princípio do valor social do trabalho humano em seu desdobramento de Garantia (Relativa) do Emprego,

\footnotetext{
${ }^{52}$ GOMES, Orlando. Dispensa coletiva na reestruturação da empresa - Aspectos jurídicos do desemprego tecnológico. Disponível em: <http://blogdopancotti.blogspot.com.br/2012/08/dispensa-coletiva-nareestruturacao-da.html>. Acesso em: 16 ago. 2016.

53 BRANCO, Ana Paula Tauceda. A colisão dos princípios constitucionais no direito do trabalho. São Paulo: LTr, 2007, p. 65.
} 
A (DES)NECESSIDADE DE REGULAMENTAÇ̃̃O DA DISPENSA COLETIVA NO BRASIL: UMA ANÁLISE SOB A ÓTICA DO VALOR SOCIAL DO TRABALHO E DA DIGNIDADE DA PESSOA HUMANA

protegendo a relação de emprego contra as dispensas arbitrárias ou sem justa causa ao invés de deixá-las ao arbítrio do interesse econômico e empresarial, fazendo letra morta dessas normas fundamentais através de uma interpretação que não guarda qualquer coerência com o atributo da regra legal em apreço dessa norma de aplicabilidade imediata. ${ }^{54}$

De acordo com José Antônio Pancotti ${ }^{55}$, enquanto se verifica a falta de regramento, a matéria em discussão vem sendo suprida em alguns acordos e convenções coletivas através da introdução de cláusulas que estabelecem os mais variados critérios para a demissão coletiva, inspirados geralmente nos costumes (por exemplo, Plano de Demissão Voluntária - PDV) ou nas diretrizes da Convenção n $\mathrm{n}^{\circ} 158$ da $\mathrm{OIT}^{56}$.

Também em decorrência da falta de sensibilização do Legislativo, convém realçar, com muito maior propriedade, o papel que tem sido desempenhado pelo exercício do poder normativo da Justiça do Trabalho, que tem sido muito mais sensível a essas questões, mormente no âmbito de primeiro grau de jurisdição, que, como se sabe, é exercido principalmente pelos Tribunais Regionais do Trabalho. ${ }^{57}$ Logo:

O Poder Normativo da Justiça do Trabalho vem sendo provocado justamente porque, não havendo regras jurídicas no sistema, de alguma maneira os atores sociais se vêem compelidos à criá-las caso a caso. As únicas maneiras de criação de normas jurídicas trabalhistas, além da legislação, são o contrato coletivo de trabalho e a sentença normativa. O conflito coletivo, entretanto, deve ser uma última instância, recorrível se a negociação e a legislação não forem eficientes no caso concreto. Não é salutar deixar que tudo seja resolvido pelo conflito direto ou intermediado de forças. ${ }^{58}$

A partir disso, desde 2009, em julgamento de dissídio coletivo acerca da despedida de mais de 4 mil trabalhadores por uma grande empresa, em face de grave retração econômica, fixou a Seção de Dissídios Coletivos do Tribunal Superior do Trabalho (TST), por maioria dos votos, a premissa de que a negociação coletiva é imprescindível para a dispensa em massa de

\footnotetext{
54 BRANCO, Ana Paula Tauceda. A colisão dos princípios constitucionais no direito do trabalho. São Paulo: LTr, 2007, p. 69.

${ }^{55}$ PANCOTTI, José Antônio. Aspectos jurídicos da dispensa coletiva no Brasil. Revista do Tribunal Regional do Trabalho da 15a Região, Campinas, n. 35, p. 39-67, 2009.

${ }^{56}$ Mencionada Convenção veio a estabelecer alternativas de regulamentação para o enfrentamento da crise, com a finalidade de regular o término da relação de trabalho por iniciativa do empregador e estabelecer garantias contra a dispensa individual ou coletiva, disciplinando-as de modo diverso. 0 documento foi ratificado pelo Brasil em 4 de abril de 1995, para vigorar doze meses depois; porém, foi denunciada pouco tempo depois, em 20 de novembro de 1996.

${ }^{57}$ COSTA, Orlando Teixeira da. Direito coletivo do trabalho e crise econômica. São Paulo: LTr, 1991.

${ }^{58}$ GONÇALVES JÚNIOR, Mário. Demissão coletiva. Academia Brasileira de Direito, 3 jan. 2007. Disponível em: $\quad$ <http://www.abdir.com.br/doutrina/ver.asp?art_id=869\&categoria=Lei\%20Pel\%C3\%83\%C2\%A9>. Acesso em: 16 ago. 2016.
} 
A (DES)NECESSIDADE DE REGULAMENTAÇÃO DA DISPENSA COLETIVA NO BRASIL: UMA ANÁLISE SOB A ÓTICA DO VALOR SOCIAL DO TRABALHO E DA DIGNIDADE DA PESSOA HUMANA

trabalhadores. Esse julgamento teve o importante condão de estabelecer a diferenciação jurídica efetiva entre dispensas meramente individuais e dispensas coletivas. Nesse quadro, enfatizou o contingenciamento constitucional dirigido às dispensas massivas, as quais deveriam se submeter à negociação coletiva trabalhista, apta a atenuar os drásticos efeitos sociais e econômicos dessa medida. ${ }^{59}$

\section{A (DES)NECESSIDADE DE REGULAMENTAÇÃO DA DISPENSA COLETIVA NO BRASIL}

Indiscutivelmente, a sociedade sofre uma crise sem precedentes, afinal, vive-se um afrouxamento de valores. Isso tem reflexo evidente no âmbito do Direito, visto se tratar de uma ciência social e, como tal, intimamente ligada à dinâmica social. Desta feita, os rumos que perpassam a sociedade geram ego imediato, ou pelo menos deveriam gerar, no seio da ciência jurídica. ${ }^{60}$

À conta disso, por esta ser uma geração de profissionais e estudiosos do Direito, vivencia-se este momento histórico de uma “crise" inimaginável, pois, no que concerne à própria ciência do Direito e, especialmente, no que tange ao sistema jurídico nacional, esse afrouxamento de valores é patente e, sem dúvida, na perspectiva holística da sociedade e do Estado, vem influenciando sobremaneira o Direito, na pessoa de seus pensadores e profissionais, a ponto de, por vezes, parecer fragilizar aos seus próprios institutos fundantes. ${ }^{61}$ É certeiro que a mencionada crise atingiu em cheio a regulação das relações individuais e coletivas de trabalho humano, propondo-lhe mutações, por vezes teratogênicas, em nome da “modernização" de seus fundamentos elementares e, por que não, das premissas constitucionais vigentes, na medida em que atinge e afeta, violentamente, a proteção de direitos fundamentais constitucionais. ${ }^{62}$

Um dos problemas a serem enfrentados na análise dos direitos sociais, como um todo, diz respeito justamente à sua efetivação/concretização. Como alerta Rubio, tende-se a reduzir sua efetividade somente ao momento em que um tribunal possua a sensibilidade interpretativa de garanti-los, tendo a sensação de que a existência de um direito humano se manifesta e

\footnotetext{
${ }^{59}$ DELGADO, Maurício Godinho. Curso de direito do trabalho. 11 ed. São Paulo: LTr, 2012.

60 BRANCO, Ana Paula Tauceda. A colisão dos princípios constitucionais no direito do trabalho. São Paulo: LTr, 2007.

61 Ibidem.

${ }^{62}$ Ibidem.
} 
A (DES)NECESSIDADE DE REGULAMENTAÇ̃̃O DA DISPENSA COLETIVA NO BRASIL: UMA ANÁLISE SOB A ÓTICA DO VALOR SOCIAL DO TRABALHO E DA DIGNIDADE DA PESSOA HUMANA

aparece apenas no momento em que é violado ou vulnerado. ${ }^{63}$ Então, esta real efetividade dependeria, em grande parte, da adoção de múltiplas e variadas medidas em todos os campos de ação: político, jurídico, social, econômico, cultural e tecnológico. ${ }^{64} \mathrm{E}$ é somente a partir da institucionalização dos direitos que se poderá reconhecer o seu caráter normativo-vinculante. Nesta medida, Robert Alexy reconhece que os direitos do homem "devem ser transformados em direito positivo para que seu cumprimento seja garantido". ${ }^{65}$

Apesar de o Direito do Trabalho ter por objeto, primordialmente, a proteção do trabalhador subordinado, hipossuficiente, na relação clássica do contrato de trabalho, permanecem os trabalhadores brasileiros à margem de qualquer garantia formal de emprego e sustento, visto inexistirem regras positivas que coíbem a dispensa em massa como artifício empresarial de diminuição de custos em sua produção. ${ }^{66}$

Nunca se deve olvidar que cabe ao Direito em geral, e ao Direito do Trabalho em particular, o papel relevante de redistribuir a riqueza e a apropriação dela. E para que ele desempenhe este nobre papel que the é destinado, impõe-se a sua adaptação aos novos tempos, porém, esta adaptação precisa ser no sentido preservacionista da ética, da justiça, a qual somente é possível com a ampliação de tutelas e o alargamento do Direito do Trabalho. Esse procedimento deve abranger as novas relações decorrentes do novo modo de produção, organização e gerência, significando esta tutela a construção e aplicação de mecanismos capazes de possibilitar inclusão social, participação na riqueza, combater a insegurança social que tem se revelado inerente ao processo ${ }^{67}$. Para Souto Maior:

A questão crucial, que se opõe à efetividade dos direitos trabalhistas, é o desemprego, mas este não pode ser, em hipótese alguma, creditado ao direito do trabalho. [...] Aliás, o discurso prevalecente, que se volta sempre para o equívocos das leis, pregando a flexibilização e a desregulamentação, que tem como pano de fundo a redução dos custos do trabalho, impede que se possa pensar no efetivo aprimoramento das relações de trabalho, que pressupõe, em

\footnotetext{
${ }^{63}$ RUBIO, David Sánchez. Crítica a una cultura estática y anestesiada de derechos humanos. Por una recuperación de las dimensiones constituyentes de la lucha por los derechos. Derechos y libertades, Madri, n. 33, época II, p. 99-134, jun. 2015. p. 105.

${ }^{64}$ FONSECA, Maria Hemilia. Direito ao trabalho: um direito fundamental no ordenamento jurídico brasileiro. São Paulo: LTr, 2009.

65 Ibidem. p. 85.

${ }^{66}$ PÔRTO, Marcos da Silva. A terminação do contrato de emprego. In: GIORDANI, Francisco Alberto da Motta Peixoto; MARTINS, Melchíades Rodrigues; VIDOTTI, Tarcio José. (Coords.). Fundamentos dos direito do trabalho: Estudos em homenagem ao Ministro Milton de Moura França. São Paulo: LTr, 2000.

${ }^{67}$ JUCÁ, Francisco Pedro. Renovação do Direito do Trabalho: abordagem alternativa à flexibilização. São Paulo: LTr, 2000.
} 
A (DES)NECESSIDADE DE REGULAMENTAÇÃO DA DISPENSA COLETIVA NO BRASIL: UMA ANÁLISE SOB A ÓTICA DO VALOR SOCIAL DO TRABALHO E DA DIGNIDADE DA PESSOA HUMANA

NELMA KARLA WAIDEMAN FUKUOKA VICTOR HUGO ALMEIDA

grande medida, a adoção de um novo tipo de regulação, e não, simplesmente, a ausência de normas. ${ }^{68}$

No mundo dos fatos, o ordenamento jurídico, de modo geral, tenta contribuir com a recuperação econômica das empresas e incentivar a produção capitalista sem desconsiderar a posição social dos trabalhadores. Seus remédios, totalmente excepcionais e temporários, não legitimam a aniquilação de empregos ou impõem sofrimentos aos trabalhadores. A lógica trazida, na verdade, é a de que devem ocorrer sacrifícios recíprocos aos empregados e ao empregador,

pressupondo-se que esses remédios vigorem, necessariamente, por prazo determinado, vez que seu propósito é o da retomada da condição econômica anterior e não o de eternizar o retrocesso (desautorizado pelo "caput" do artigo $7^{\circ}$, da CF e pelos princípios consagrados na teoria dos direitos fundamentais). ${ }^{69}$

Silva, ao citar o economista Edward J. Amadeo, alerta:

[...] o principal indicador de baixa qualidade dos empregos é o índice de rotatividade. Cerca de $50 \%$ dos trabalhadores do setor formal estão há menos de dois anos no mesmo emprego... A elevada rotatividade do emprego é uma evidência de que o custo da demissão não é alto. Parece ser mais barato demitir e readmitir um trabalhador do que preservar o seu emprego ao longo de um ciclo econômico. [...] com a perspectiva de uma relação de emprego mais duradoura, tanto empregado quanto empregador passam a ter uma atitude mais cooperativa, aumentando a produtividade - o que reduz o "custo Brasil" e aumenta a competitividade. $^{70}$

Essa facilitação e esse "barateamento" da dispensa, analisados pelo economista citado, é um dos fatores do desemprego. Uma das medidas para evitá-lo é, então, a limitação do direito de dispensar, fato reconhecido até mesmo numa visão econômica do problema ${ }^{71}$. Segundo Antônio Álvares da Silva:

Precisamos ter uma justa medida e procurar a linha, nem sempre nítida e perceptível, do que sejam medidas protecionistas que dificultam a produtividade e encarecem o trabalho e proteção social necessária do trabalhador para que a

\footnotetext{
${ }^{68}$ SOUTO MAIOR, Jorge Luiz. O direito do trabalho como instrumento de justiça social. São Paulo: LTr, 2000, p. 164-165.

${ }^{69}$ SOUTO MAIOR, Jorge Luiz. PDV: o “neoliberalismo" extemporâneo de Zago e a responsabilidade do Conselho. Disponível em: <http://cartamaior.com.br/?/Editoria/Educacao/PDV-o-neoliberalismoextemporaneo-de-Zago-e-a-responsabilidade-do-Conselho/13/31732\&page=1>. Acesso em: 16 ago. 2016.

${ }^{70}$ AMADEO apud SILVA, Antônio Álvares da. Questões polêmicas de direto do trabalho: a Convenção 158 da OIT e a garantia no emprego; Juizado Especial de causas trabalhistas. São Paulo: LTr, 1996. v. 8. p. 20.

71 SILVA, Antônio Álvares da. Questões polêmicas de direto do trabalho: a Convenção 158 da OIT e a garantia no emprego; Juizado Especial de causas trabalhistas. São Paulo: LTr, 1996. v. 8.
} 
A (DES)NECESSIDADE DE REGULAMENTAÇÃO DA DISPENSA COLETIVA NO BRASIL: UMA ANÁLISE SOB A ÓTICA DO VALOR SOCIAL DO TRABALHO E DA DIGNIDADE DA PESSOA HUMANA

prestação de trabalho permaneça num nível de justiça e equilíbrio social. Caso contrário, sacrifica-se o social sem se beneficiar o econômico. ${ }^{72}$

Nesse contexto, a atualização do Direito do Trabalho é necessária para enfrentar os desafios do próximo milênio, dentre os quais o desemprego constitui-se uma das principais ameaças. A solução não deve se restringir ao campo econômico, cabendo ao Direito do Trabalho papel decisivo e preponderante, não se submetendo, para isso, pura e simplesmente às regras ditadas pela economia, embora o conteúdo das regras a serem ditadas pelo Direito tenha forte conteúdo socioeconômico. ${ }^{73}$ Aliás, a manutenção de um Direito do Trabalho com base na predominância do interesse social e nos Direitos Humanos.

Portanto, a proteção contra a dispensa coletiva é de extrema importância nos presentes dias, tendo em vista a alteração causada no mundo do trabalho pela Terceira Revolução Industrial, ou seja, a passagem do fordismo para o toyotismo - mesmo que no Brasil o toyotismo ainda não seja um modelo uniforme, pois se mistura com o fordismo ${ }^{74}$. Para Cláudio Janotti da Rocha:

No novo paradigma do trabalho e do emprego, suscitado pela substituição das formas clássicas de trabalho com base no modelo taylorista e fordista pelo advento do trabalho com base na era da informação e do conhecimento, que tem como característica uma prestação de serviços mais flexível, precária de certa forma desprotegida das garantias tradicionais de estabilidade e segurança no emprego, cabe um papel fundamental ao Direito do Trabalho na contribuição da crise do emprego. ${ }^{75}$

Existem muitos questionamentos quanto à realização da dimensão coletiva do direito ao trabalho, principalmente quanto à sua efetivação. Contudo, "quando o constituinte brasileiro fez menção à 'busca do pleno emprego' como um dos princípios a ser atendido pela ordem econômica, constitucionalizou esta ação como uma obrigação, e não como uma mera opção". ${ }^{76}$ Ora, já mais do que chegou a vez do Direito do Trabalho viver e conviver com o fenômeno da constitucionalização. $\mathrm{O}$ ato do empregador que extinguir os contratos de trabalho de maneira

\footnotetext{
72 SILVA, Antônio Álvares da. Questões polêmicas de direto do trabalho: a Convenção 158 da OIT e a garantia no emprego; Juizado Especial de causas trabalhistas. São Paulo: LTr, 1996. v. 8, p. 20-21.

73 Ibidem.

${ }^{74}$ ROCHA, Cláudio Jannotti da. Reflexões sobre a dispensa coletiva brasileira. Rev. Trib. Reg. Trab. $3^{a}$ Reg., Belo Horizonte, v. 51, n. 81, p. 219-228, jan./jun. 2010.

${ }^{75}$ Ibidem. p. 281.

76 FONSECA, Maria Hemilia. Direito ao trabalho: um direito fundamental no ordenamento jurídico brasileiro. São Paulo: LTr, 2009, p. 152-153.
} 
A (DES)NECESSIDADE DE REGULAMENTAÇÃO DA DISPENSA COLETIVA NO BRASIL: UMA ANÁLISE SOB A ÓTICA DO VALOR SOCIAL DO TRABALHO E DA DIGNIDADE DA PESSOA HUMANA

NELMA KARLA WAIDEMAN FUKUOKA VICTOR HUGO ALMEIDA

massiva por motivos de causa objetiva sempre será delimitado pelos direitos fundamentais do trabalhador à luz do ditame constitucional. ${ }^{77}$

Apesar da previsão constitucional, doutrina e jurisprudência dominantes, após 5 de outubro de 1988, tenderam a compreender que os preceitos dos incisos I e XXI do art. $7^{\circ}$ constitucional não teriam o condão de produzir efeitos imediatos, na qualidade de normas programáticas que seriam ${ }^{78}$. 0 tempo que corre inexorável, quase vinte e dois anos da promulgação da Carta Magna, consagra no mundo dos fatos a perenidade de norma que nasceu com o caráter de provisória ${ }^{79}$. Nas palavras de Mário Gonçalves Júnior:

Esse descompasso está chegando ao ponto de se tornar também irreversível:
desde as privatizações, demissões coletivas ocorreram aos montes e a sociedade
não contou com defesas específicas. Hordas de empregos foram dizimadas,
lançando os respectivos trabalhadores à própria sorte. Ainda que venhamos a
finalmente alterar o Direito do Trabalho - para torná-lo mais coletivo e menos
individualista -, em especial quanto às demissões coletivas arbitrárias, é bem
provável que a sociedade brasileira já terá feito por conta própria suas
"reformas" no mercado de trabalho com a legislação trabalhista disponível,
assumindo as consequências legais comuns para demissões sem justa causa,
arbitrárias ou não. ${ }^{80}$

Mas é preciso deixar claro o caráter dirigente de Constituição Federal de 1988, negando a procedimentalidade dos seus princípios e caracterizando-os como substantivos e até mesmo compromissórios, porém, dotados de normatividade suficiente para sua aplicação e interpretação ${ }^{81}$. Para Pablo Sá Domingues:

Eis que surge como epicentro constitucional a dignidade da pessoa humana cuja atenção é obrigatória tanto pelo Estado quanto pela sociedade. Isso se mostra ao passo que todo princípio constitucional possui o seu núcleo duro, seu mínimo existencial que deve ser preservado sob qualquer circunstância para resguardo de

\footnotetext{
77 DOMINGUES, Pablo Sá. Crise econômica, dispensa coletiva \& preservação de empregos. 2010. $86 \mathrm{f}$. Monografia (Graduação em Direito) - Escola de Direito FGV, FGV, Rio de Janeiro, 2010. Disponível em: <http://bibliotecadigital.fgv.br/dspace/bitstream/handle/10438/10317/Pablo\%20S\%C3\%A1\%20Domingues. pdf?sequence=1>. Acesso em: 16 ago. 2016.

${ }_{78}$ DELGADO, Maurício Godinho. Curso de direito do trabalho. 11 ed. São Paulo: LTr, 2012.

79 PAULA, Carlos Alberto Reis de. Dispensa coletiva e negociação. Rev. TST, Brasília, v. 77, n. 2, abr./jun. 2011. Disponível em: <http://aplicacao.tst.jus.br/dspace/bitstream/handle/1939/25343/016_paula.pdf?sequence=4>. Acesso em: 16 ago. 2016.

${ }^{80}$ GONÇALVES JÚNIOR, Mário. Demissão coletiva. Academia Brasileira de Direito, 3 jan. 2007. Disponível em: $\quad$ <http://www.abdir.com.br/doutrina/ver.asp?art_id=869\&categoria=Lei\%20Pel\%C3\%83\%C2\%A9>. Acesso em: 16 ago. 2016.

${ }^{81}$ DOMINGUES, Pablo Sá. Crise econômica, dispensa coletiva \& preservação de empregos. 2010. $86 \mathrm{f}$. Monografia (Graduação em Direito) - Escola de Direito FGV, FGV, Rio de Janeiro, 2010. Disponível em: <http://bibliotecadigital.fgv.br/dspace/bitstream/handle/10438/10317/Pablo\%20S\%C3\%A1\%20Domingues. pdf?sequence=1>. Acesso em: 16 ago. 2016.
} 
cada indivíduo e da própria sociedade. Frente a estas considerações é com grande satisfação que se constata a vinculação direta de todos atores sociais aos direitos fundamentais, caracterizando o efeito horizontal dos mesmos, conferindo materialidade, aplicabilidade imediata (irradiação) no cotidiano das relações intersociais. ${ }^{82}$

A partir dessa visão constitucional, os direitos e garantias surtem efeitos horizontais, o que abre espaço para o ativismo judicial. Na omissão do legislador que não procura assegurar ao trabalhador sua dignidade mediante edição de lei que proteja sua relação empregatícia contra a despedida arbitrária ou sem justa causa é imperativa a conduta jurisdicional para salvaguardar tais direitos. ${ }^{83}$ Mas cabe uma ressalva:

Ora, as decisões mencionadas são difusoras no sistema jurídico pátrio, mas os $\mathrm{E}$. TRT's ao concluírem pelo vício no negócio jurídico e pela ilicitude na conduta dos agentes envolvidos restringiram-se, pois: ou determinaram as empresas a indenizar os obreiros (com diversas formas), ou remeteram as partes a um acordo específico para as demissões. Outros mecanismos jurídicos poderiam ter sido utilizados e mais efetividade às normas trabalhistas alcançadas, incluindo, aplicações de sanções às empresas. Porém, o marco difusor foi a consideração e evidencialidade pacífica de abusividade e ilicitude nas condutas dos empregadores em praticarem as demissões em massa, e sempre unilaterais. $\left(\right.$ grifamos) ${ }^{84}$

Nesse sentido, algumas ideias legislativas têm surgido para socorrer o descalabro descumprimento dos preceitos assegurados aos trabalhadores e aos representantes de classes. Como o Projeto de Lei (PL) n 6.356/2005 que, em suma, prevê “índices” para a adoção da demissão coletiva nos casos descritos e remete as partes à negociação coletiva. ${ }^{85}$

A partir dos fatos desencadeados com a crise de 2008, os deputados Ivan Valente e Manuela D’Ávila (PCdoB), juntamente com outros mais, apresentaram o Projeto de Lei 5.353/2009, que ora tramita na Câmara dos Deputados, aguardando apreciação conclusiva das Comissões Legislativas. No PL, o legislador claramente se inspirou no direito estrangeiro e acertadamente atendeu aos comandos constitucionais de proteção ao trabalhador e promoção

\footnotetext{
82 DOMINGUES, Pablo Sá. Crise econômica, dispensa coletiva \& preservação de empregos. 2010. $86 \mathrm{f}$. Monografia (Graduação em Direito) - Escola de Direito FGV, FGV, Rio de Janeiro, 2010. Disponível em: <http://bibliotecadigital.fgv.br/dspace/bitstream/handle/10438/10317/Pablo\%20S\%C3\%A1\%20Domingues. pdf?sequence=1>. Acesso em: 16 ago. 2016.

${ }_{83}$ Ibidem.

${ }^{84}$ TEODORO, Maria Cecília Máximo; SILVA, Aarão Miranda da. A imprescindibilidade da negociação coletiva nas demissões em massa e a limitação de conteúdo constitucionalmente imposta. Âmbito Jurídico, Rio Grande, XII, n. 64, maio 2009. Disponível em: <http://www.ambitojuridico.com.br/site/index.php?n_link=revista_artigos_leitura\&tartigo_id=6082>. Acesso em: 16 ago. 2016.

${ }^{85}$ BRASIL. Projeto de Lei $\mathrm{n}^{\circ}$ 6.356, de 7 dez. 2005. Regulamenta a demissão coletiva e determina outras providências. Câmara dos Deputados, Brasília, 7 dez. 2005 . Documento disponível em <http://www.camara.gov.br/sileg/integras/362814.pdf>. Acesso em: 16 ago. 2016.
} 
A (DES)NECESSIDADE DE REGULAMENTAÇÃO DA DISPENSA COLETIVA NO BRASIL: UMA ANÁLISE SOB A ÓTICA DO VALOR SOCIAL DO TRABALHO E DA DIGNIDADE DA PESSOA HUMANA

NELMA KARLA WAIDEMAN FUKUOKA VICTOR HUGO ALMEIDA

do diálogo entre as partes com a devida participação dos sindicatos representativos de categorias. $^{86}$

Se a dispensa individual, por si só, já deve observar o papel social do trabalho, a coletiva, então, deve ser tratada com maiores cuidados ainda, uma vez que afeta de forma considerável todo um grupo, com reflexos maiores na própria sociedade. Uma dispensa coletiva causa um impacto bem maior do que uma dispensa individual, e, em consequência, não pode obedecer à mesma lógica e tampouco merecer o mesmo tratamento jurídico. Uma despedida em massa deve merecer e receber uma maior regulação jurídica ${ }^{87}$. Na opinião de Francisco Pedro Jucá:

Embora possa parecer, em princípio, contradição, não é simplificando e diminuindo pela chamada desregulamentação das relações que se enfrenta adequadamente o problema, mas, ainda que suprimindo formalidades, é ampliando as formas de regulamentação, tornando-as mais largas, mais ampliadas, mais capazes de albergar as novas figuras e os novos modos. ${ }^{88}$

A partir disso, pode-se constatar que os pressupostos do regime geral do Direito do Trabalho contemporâneo sobre a proteção da relação de emprego na despedida individual são insuficientes para fazer frente à gravidade do fenômeno da dispensa coletiva ${ }^{89}$. Porém, cabe refletir que:

\begin{abstract}
Estamos bastante atrasados, mas a dispensa coletiva permanece chaguenta -.talvez menos purulenta do que no auge das privatizações -.-, pois é imprevisível aonde a globalização e as profundas transformações do mercado de trabalho ainda nos levarão. Essas mudanças, ainda em pleno curso e avassaladoras, impõem-nos atualmente reformar todo o direito material do trabalho, de maneira que hoje a regulamentação da demissão coletiva, sozinha, provavelmente seria outro remendo. Mas, ainda assim: ruim sem ela, pior sem ela. Mesmo que teimemos no Direito do Trabalho de Vargas, a demissão coletiva continuará reclamando alguma regulamentação. ${ }^{90}$
\end{abstract}

\footnotetext{
${ }^{86}$ DOMINGUES, Pablo Sá. Crise econômica, dispensa coletiva \& preservação de empregos. 2010. $86 \mathrm{f}$. Monografia (Graduação em Direito) - Escola de Direito FGV, FGV, Rio de Janeiro, 2010. Disponível em: <http://bibliotecadigital.fgv.br/dspace/bitstream/handle/10438/10317/Pablo\%20S\%C3\%A1\%20Domingues. pdf?sequence=1>. Acesso em: 16 ago. 2016.

${ }^{87}$ ROCHA, Cláudio Jannotti da. Reflexões sobre a dispensa coletiva brasileira. Rev. Trib. Reg. Trab. $3^{\text {a }}$ Reg., Belo Horizonte, v. 51, n. 81, p. 219-228, jan./jun. 2010.

${ }_{88}$ JUCÁ, Francisco Pedro. Renovação do Direito do Trabalho: abordagem alternativa à flexibilização. São Paulo: LTr, 2000, p. 90.

${ }^{89}$ PANCOTTI, José Antônio. Aspectos jurídicos da dispensa coletiva no Brasil. Revista do Tribunal Regional do Trabalho da $15^{\text {a }}$ Região, Campinas, n. 35, p. 39-67, 2009.

${ }^{90}$ GONÇALVES JÚNIOR, Mário. Demissão coletiva. Academia Brasileira de Direito, 3 jan. 2007. Disponível em: <http://www.abdir.com.br/doutrina/ver.asp?art_id=869\&categoria=Lei\%20Pel\%C3\%83\%C2\%A9>. Acesso em: 16 ago. 2016.
} 
A (DES)NECESSIDADE DE REGULAMENTAÇ̃̃O DA DISPENSA COLETIVA NO BRASIL: UMA ANÁLISE SOB A ÓTICA DO VALOR SOCIAL DO TRABALHO E DA DIGNIDADE DA PESSOA HUMANA

Neste contexto é que deve ser identificado e compreendido o direito à garantia de emprego contra o despedimento arbitrário ou injusto, segundo o disposto no art. $7^{\circ}$, inciso I, da Constituição Federal de 1988, a partir do qual também deve ser analisada a questão relacionada com a obtenção da sua real eficácia jurídica, principalmente nas questões de dispensas coletivas. $\mathrm{O}$ inciso $\mathrm{I}$ do art. $7^{\circ}$ da Constituição não se apresenta como norma de eficácia plena, mas como norma de eficácia limitada, pois deve o legislador complementá-la. A lei complementar, para Sérgio Pinto Martins, "tanto dirá respeito à indenização compensatória, como à proteção da relação de emprego" ${ }^{91}$.

Para José Afonso da Silva, a lei complementar pode estabelecer outros direitos, que já não sejam previstos na própria Constituição, devendo ser um “direito novo”. Explica:

Por exemplo, poderá vedar despedidas coletivas, obrigar que o trabalhador admitido em lugar de outro despedido tenha o mesmo salário. Terá que definir o que seja despedida arbitrária e despedida sem justa causa, o que não é difícil, pois a leis trabalhistas em vigor já o fazem, e valem até que sejam modificadas, no particular, pela referida lei complementar. É que, na espécie, funciona o princípio da recepção, como complementar, da lei existente sobre assunto. ${ }^{92}$

Algumas diretrizes à lei complementar também são apontadas por Souto Maior, no sentido de que, numa cessação coletiva, a iniciativa do empregador deve se basear em "real necessidade, devidamente comprovada, sendo precedida de um Plano de Recuperação, do qual participem também os trabalhadores e o próprio Estado" ${ }^{93}$. Explica o autor que:

A lógica é a de que ocorram sacrifícios recíprocos aos empregados e ao empregador, pressupondo-se que esses remédios vigorem, necessariamente, por prazo determinado, vez que seu propósito é o da retomada da condição econômica anterior e não o de eternizar o retrocesso (desautorizado pelo "caput" do artigo $7^{\circ}$., da CF e pelos princípios consagrados na teoria dos direitos fundamentais). ${ }^{94}$

0 projeto de lei que se dignar a tratar sobre dispensas coletivas por motivos objetivos adversos deverá contemplar a negociação coletiva como ferramenta principal para a preservação de empregos ${ }^{95}$ (mesmo as normas jurídicas já possibilitando uma ampla liberdade sindical, com

\footnotetext{
${ }_{91}^{91}$ MARTINS, Sérgio Pinto. Direito do Trabalho. 28. ed. São Paulo: Atlas, 2012, p. 218.

${ }^{92}$ SILVA, José Afonso da. Curso de direito constitucional positivo. 35. ed. São Paulo: Malheiros, 2011, p. 291.

${ }_{93}$ SOUTO MAIOR, Jorge Luiz. O direito do trabalho como instrumento de justiça social. São Paulo: LTr, 2000.

${ }^{94}$ Ibidem.

${ }^{95}$ DOMINGUES, Pablo Sá. Crise econômica, dispensa coletiva \& preservação de empregos. 2010. $86 \mathrm{f}$. Monografia (Graduação em Direito) - Escola de Direito FGV, FGV, Rio de Janeiro, 2010. Disponível em:
} 
A (DES)NECESSIDADE DE REGULAMENTAÇ̃̃O DA DISPENSA COLETIVA NO BRASIL: UMA ANÁLISE SOB A ÓTICA DO VALOR SOCIAL DO TRABALHO E DA DIGNIDADE DA PESSOA HUMANA

NELma KarLa WAideman FUKUOKa VICTOR HUGO ALMEIDA

efetivação da atividade negocial e respeito ao Direito do Trabalho, bastando a aplicação dos tratados internacionais, das normas constitucionais e infraconstitucionais). ${ }^{96}$ Nessa discussão poder-se-ia lembrar que o espaço da negociação coletiva é justamente este de aprimorar e atualizar a legislação. Mas, em épocas de crise, o poder negocial dos trabalhadores é sensivelmente reduzido e estes praticamente lutam para não perder as conquistas já auferidas ${ }^{97}$. Por isso, é preciso, ao mínimo, que se leve ao Poder Legislativo um projeto seguro e efetivo de reforma sindical, atribuindo-se aos sindicatos, dentre outras reformas necessárias, a obrigação de se impor às empresas a participação sindical sempre que ocorrerem demissões em massa. ${ }^{98}$

A reconstrução da normatividade do mundo do trabalho, nesse viés, nega a desregulamentação do tema, por entender que é impossível e impraticável num país de organização social e econômica tão complexa como o nosso, remeter temas tão fundamentais à autonomia coletiva da vontade, quando sabidamente apenas em uma minoria ela realmente pode ser expressa idônea e viavelmente. ${ }^{99}$ Não é viável, na concepção de Jucá, que se pretenda estabelecer um ato único. Mas, antes disso, um processo de manutenção gradual e de convivência de diversas ordens de tutelas, porque todas são necessárias em circunstâncias específicas. Por exemplo, deve ser preservado um espaço para a atuação da fonte negocial. ${ }^{100}$

E, nesse ponto, nos incumbe analisar as ponderações de Antônio Álvares da Silva:

A intervenção do legislador é apenas compensatória e regulativa. Serve para aumentar o poder dos fracos para enfrentar o poder econômico e social dos mais poderosos. Mas uma mudança na relação de poder, tornando-se o fraco mais forte do que os fortes, jamais se deu por obra do legislador. Portanto aos sindicatos resta o exercício de sua liberdade que consiste na negociação coletiva, cujo conteúdo principal é exatamente obter regras mais favoráveis que, sem a formalidade e a demora das leis dos parlamentos, operem esta compensação com

<http://bibliotecadigital.fgv.br/dspace/bitstream/handle/10438/10317/Pablo\%20S\%C3\%A1\%20Domingues. pdf?sequence=1>. Acesso em: 16 ago. 2016.

${ }_{96}$ TEODORO, Maria Cecília Máximo; SILVA, Aarão Miranda da. A imprescindibilidade da negociação coletiva nas demissões em massa e a limitação de conteúdo constitucionalmente imposta. Âmbito Jurídico, Rio Grande, XII, n. 64, maio 2009. Disponível em: <http://www.ambitojuridico.com.br/site/index.php?n_link=revista_artigos_leitura\&tartigo_id=6082>. Acesso em: 16 ago. 2016. ${ }_{97}$ SOUTO MAIOR, Jorge Luiz. 0 direito do trabalho como instrumento de justiça social. São Paulo: LTr, 2000.

${ }_{98}$ VIALÔGO, Tales Manoel Lima; NEGREIROS, Guilherme Enei Vidal de. A demissão coletiva no direito brasileiro. Revista JurisFIB, Bauru, v. III, a. III, dez. 2012. Disponível em: <http:/ / www.revistajurisfib.com.br/artigos/1359118566.pdf>. Acesso em: 16 ago. 2016.

99 JUCÁ, Francisco Pedro. Renovação do Direito do Trabalho: abordagem alternativa à flexibilização. São Paulo: LTr, 2000, p. 112.

${ }^{100}$ Ibidem. P. 113. 
rapidez e eficiência, atendendo-se às necessidades e contingências do momento histórico. ${ }^{101}$

Num exercício interpretativo mais preciso, observa-se que as normas jurídicas já possibilitam uma ampla liberdade sindical. Com efetivação da atividade negocial e respeito ao Direito do Trabalho, bastaria a aplicação dos tratados internacionais, das normas constitucionais e infraconstitucionais. ${ }^{102}$

Por decorrência, o Brasil necessita da ratificação da Convenção n 158 da OIT, em todo o seu conteúdo acerca da demissão em massa, adotando-se o instituto da "ampla negociação coletiva" (para aquilo que a negociação seja possível) ${ }^{103}$, podendo, especialmente nas relações de trabalho mais tradicionais, ter amplitude mais acentuada. ${ }^{104}$ Ou seja, a lei complementar deverá tratar das restrições legais de direitos, não afeitos à negociação coletiva. ${ }^{105}$

$E$, tomando o diploma legal internacional como base, além dos estudos de direito comparado, "necessita da formulação de normas com eficácia e garantia de segurança jurídica plena, especialmente quanto aos critérios quantitativos de desligamentos para que se considere demissão coletiva". ${ }^{106}$ Esta ampliação também pressupõe a manutenção da presença do Estado, como poder político institucionalizado, intermediando o processo de convivência conflitual inerente à vida em sociedade ${ }^{107}$. 0 direito é a via que a sociedade possui para viver em um sistema contributivo de solidariedade, mas o Estado é o ente garantidor dessa ferramenta. ${ }^{108}$ Para Rubio,

\footnotetext{
${ }^{101}$ SILVA, Antônio Álvares da. Questões polêmicas de direto do trabalho: a Convenção 158 da OIT e a garantia no emprego; Juizado Especial de causas trabalhistas. São Paulo: LTr, 1996. V. 8, p. 14-15.

102 TEODORO, Maria Cecília Máximo; SILVA, Aarão Miranda da. A imprescindibilidade da negociação coletiva nas demissões em massa e a limitação de conteúdo constitucionalmente imposta. Âmbito Jurídico, Rio Grande, XII, n. 64, maio 2009. Disponível em: <http://www.ambitojuridico.com.br/site/index.php?n_link=revista_artigos_leitura\&tartigo_id=6082>. Acesso em: 16 ago. 2016. ${ }^{103}$ Ibidem.

104 JUCÁ, Francisco Pedro. Renovação do Direito do Trabalho: abordagem alternativa à flexibilização. São Paulo: LTr, 2000.

105 TEODORO, Maria Cecília Máximo; SILVA, Aarão Miranda da. A imprescindibilidade da negociação coletiva nas demissões em massa e a limitação de conteúdo constitucionalmente imposta. Âmbito Jurídico, Rio Grande, XII, n. 64, maio 2009. Disponível em: <http://www.ambitojuridico.com.br/site/index.php?n_link=revista_artigos_leitura\&tartigo_id=6082>. Acesso em: 16 ago. 2016.

106 VIALÔGO, Tales Manoel Lima; NEGREIROS, Guilherme Enei Vidal de. A demissão coletiva no direito brasileiro. Revista JurisFIB, Bauru, v. III, a. III, dez. 2012. Disponível em: <http://www.revistajurisfib.com.br/artigos/1359118566.pdf>. Acesso em: 16 ago. 2016.

107 JUCÁ, Francisco Pedro. Renovação do Direito do Trabalho: abordagem alternativa à flexibilização. São Paulo: LTr, 2000.

${ }_{108}$ VIALÔGO, Tales Manoel Lima; NEGREIROS, Guilherme Enei Vidal de. A demissão coletiva no direito brasileiro. Revista JurisfIB, Bauru, v. III, a. III, dez. 2012. Disponível em: <http://www.revistajurisfib.com.br/artigos/1359118566.pdf>. Acesso em: 16 ago. 2016.
} 
A (DES)NECESSIDADE DE REGULAMENTAÇ̃̃O DA DISPENSA COLETIVA NO BRASIL: UMA ANÁLISE SOB A ÓTICA DO VALOR SOCIAL DO TRABALHO E DA DIGNIDADE DA PESSOA HUMANA

Parece como se existisse um espírito de impotência que, sob a desculpa da diferença entre o dito e o feito, adota a atitude de continuar a deixar as coisas como elas são, permanecendo intactas as estruturas socioculturais assimétricas e desiguais sobre as quais esta cultura de indolência se move como um peixe na água. ${ }^{109}$

Portanto, a constitucionalização, advinda com o Estado Social, consubstanciou-se na importante intenção de converter em direito positivo várias aspirações sociais, elevadas à categoria de princípios constitucionais protegidos pelas garantias do Estado de Direito ${ }^{110}$. Por fim, é cristalino que o Direito Coletivo do Trabalho no Brasil precisa ser submetido a uma verdadeira transformação para se adequar ao mundo dos fatos e ser um verdadeiro instrumento de justiça social, de redistribuição de renda e de inclusão social de largas camadas de trabalhadores que vivem hoje no limbo do desemprego.

\section{CONCLUSÃO}

O presente estudo evidenciou que, à luz dos diversos princípios, valores e regras da Constituição Federal de 1988, a proteção da relação empregatícia contra a dispensa arbitrária ou sem justa causa é um direito fundamental dos trabalhadores. Corolário lógico de tudo isso é que o trabalhador não pode sofrer sozinho, nem prioritariamente, as consequências de uma crise econômica, até mesmo porque é a parte fraca da relação. Comprovada a necessidade de uma dispensa massiva, os empregados merecem uma proteção para além da prevista para a dispensa individual. ${ }^{111}$

Como o direito legislado brasileiro não trata do assunto das dispensas coletivas, não há no ordenamento jurídico brasileiro um texto legal que a defina. Em consequência disso, prevalece no país uma fórmula que não é de todo satisfatória, conforme disposto no art. $7^{\circ}$, inciso I, que assegura a relação de emprego protegida contra despedida arbitrária ou sem justa causa, nos termos da lei complementar. A jurisprudência tem sido suscitada a suprir essa lacuna

\footnotetext{
109 "Parece como si existiera una espiritualidad de impotencia que, bajo la escusa de ese abismo entre lo dicho y lo hecho, adopta la actitud de seguir dejando las cosas como están, permaneciendo intactas las estructuras socio-culturales asimétricas y desiguales sobre las que esta cultura de desidia se mueve como pez en agua." RUBIO, David Sánchez. Op. cit., p. 102-103.

${ }_{110}$ MORAES, Alexandre de. Direito constitucional. 25. ed. São Paulo: Atlas, 2010.

111 ROCHA, Cláudio Jannotti da. Reflexões sobre a dispensa coletiva brasileira. Rev. Trib. Reg. Trab. $3^{a}$ Reg., Belo Horizonte, v. 51, n. 81, p. 219-228, jan./jun. 2010.
} 
A (DES)NECESSIDADE DE REGULAMENTAÇÃO DA DISPENSA COLETIVA NO BRASIL: UMA ANÁLISE SOB A ÓTICA DO VALOR SOCIAL DO TRABALHO E DA DIGNIDADE DA PESSOA HUMANA

para impedir que as ameaças de desemprego sejam utilizadas como argumento para a diminuição de direitos.

Mas, na busca para se equacionar a melhor fórmula de preservar empregos e, concomitantemente, buscar a sobrevivência da empresa em momentos de crise, tem-se que esta se daria pela disciplina da dispensa coletiva por causas objetivas pelo Poder Legislativo, preenchendo a atual lacuna existente; pelo Poder Judiciário que, frente ao fenômeno de constitucionalização do Direito, contemplando os direitos fundamentais na sua eficácia horizontal e na sua força normativa, aja de forma ativista a fim de impedir que trabalhadores se vejam lesados pelo abuso de exercício do direito do empregador e resguarde a sociedade empresária para sobreviver à conjuntura econômica adversa e futuramente volte a gerar externalidades positivas para a sociedade; e, finalmente, pela ação do Poder Executivo, que deve promover a ratificação da Convenção no 158 da OIT e, junto com o Congresso, internalizála no ordenamento jurídico pátrio, elaborando novas políticas públicas para empregos mediante cenário de crise econômica.

Incontestável, portanto, a certeza prevalecente na atualidade da imperativa necessidade de modernizar e atualizar o Direito do Trabalho face à realidade econômica, no sentido de enfrentar os grandes desafios próprios desse ramo do direito, dentre os quais a crise do emprego se configura como um dos mais urgentes e complexos.

\section{REFERÊNCIAS}

ANTUNES, Ricardo Luis Coltro. O continente do labor. São Paulo: Boitempo, 2011.

BRANCO, Ana Paula Tauceda. A colisão dos princípios constitucionais no direito do trabalho. São Paulo: LTr, 2007.

BRASIL. Constituição Federal. Brasília: Senado Federal, 1988. Disponível em:

<http://www.planalto.gov.br/ccivil_03/constituicao/constituicaocompilado.htm>. Acesso em: 16 ago. 2016.

BRASIL. Projeto de Lei $n^{\circ}$ 6.356, de 7 dez. 2005. Regulamenta a demissão coletiva e determina outras providências. Câmara dos Deputados, Brasília, 7 dez. 2005. Documento disponível em <http://www.camara.gov.br/sileg/integras/362814.pdf>. Acesso em: 16 ago. 2016.

COSTA, Orlando Teixeira da. Direito coletivo do trabalho e crise econômica. São Paulo: LTr, 1991.

DELGADO, Maurício Godinho. Curso de direito do trabalho. 10. ed. São Paulo: LTr, 2011. 
DELGADO, Maurício Godinho. Curso de direito do trabalho. 11 ed. São Paulo: LTr, 2012.

DOMINGUES, Pablo Sá. Crise econômica, dispensa coletiva \& preservação de empregos. 2010. 86 f. Monografia (Graduação em Direito) - Escola de Direito FGV, FGV, Rio de Janeiro, 2010. Disponível em:

<http://bibliotecadigital.fgv.br/dspace/bitstream/handle/10438/10317/Pablo\%20S\%C3\%A1\%20D omingues.pdf?sequence=1>. Acesso em: 16 ago. 2016.

FELTRE, Andrezza Nazareth. Negociação coletiva como pressuposto para a dispensa em massa. 2012. 101 f. Dissertação (Mestrado) - FUMEC, Programa de Pós-Graduação em Direito, Belo Horizonte. Disponível em:

<http://www.fumec.br/anexos/cursos/mestrado/dissertacoes/completa/andrezza_nazareth_fel tre.pdf>. Acesso em: 16 ago. 2016.

FERREIRA FILHO, Manoel Gonçalves. Curso de direito constitucional. 36. ed. rev. e atual. São Paulo: Saraiva, 2010.

FONSECA, Maria Hemilia. Direito ao trabalho: um direito fundamental no ordenamento jurídico brasileiro. São Paulo: LTr, 2009.

GODOY, Arnaldo Moraes. Globalização e Direito: a mundialização do capital e seus efeitos no modelo normativo brasileiro. Argumentum Revista de Direito, Marília, v. 3, 2003. Disponível em: <http://www.unimar.br/biblioteca/publicacoes/pos/Direito_vol_03.pdf>. Acesso em: 16 ago. 2016.

GOMES, Orlando. Dispensa coletiva na reestruturação da empresa - Aspectos jurídicos do desemprego tecnológico. Disponível em:

<http://blogdopancotti.blogspot.com.br/2012/08/dispensa-coletiva-na-reestruturacaoda.html>. Acesso em: 16 ago. 2016.

GONÇAVES, Antônio Fabrício de Matos; KNEIPP, Bruno Burgarelli Albergaria. Reestruturação produtiva, globalização e neoliberalismo: reflexos o modelo brasileiro e suas consequências na legislação trabalhista. Revista do Advogado, São Paulo, n. 121, a. XXXIII, nov. 2013.

GRAU, Eros Roberto. A ordem econômica na Constituição de 1988. 13. ed. São Paulo: Malheiros Editores, 2008.

JUCÁ, Francisco Pedro. Renovação do Direito do Trabalho: abordagem alternativa à flexibilização. São Paulo: LTr, 2000.

GONÇALVES JÚNIOR, Mário. Demissão coletiva. Academia Brasileira de Direito, 3 jan. 2007. Disponível em:

http://www.abdir.com.br/doutrina/ver.asp?art_id=869\&categoria=Lei\%20Pel\%C3\%83\%C2\%A9>. Acesso em: 16 ago. 2016.

KON, Anita. Pleno emprego no Brasil: interpretando os conceitos e indicadores. Revista Economia e Tecnologia (RET), v. 8, n. 2, p. 5-22, abr./jun. 2012. Disponível em: 
A (DES)NECESSIDADE DE REGULAMENTAÇÃO DA DISPENSA COLETIVA NO BRASIL: UMA ANÁLISE SOB A ÓTICA DO VALOR SOCIAL DO TRABALHO E DA DIGNIDADE DA PESSOA HUMANA

<http: //www.economiaetecnologia.ufpr.br/revista/Volume\%208\%20n\%202/05\%20Anita\%20Kon.p df>. Acesso em: 16 ago. 2016.

MANNRICH, Nelson. Programa de Proteção ao Emprego (PPE): timidez e burocracia. Jota, São Paulo, 6 ago. 2015. Disponível em: <http://jota.uol.com.br/programa-de-protecao-ao-empregoppe-timidez-e-burocracia>. Acesso em: 18 jul. 2016.

MARTINS, Sérgio Pinto. A continuidade do contrato de trabalho. São Paulo: Atlas, 2000.

MARTINS, Sérgio Pinto. Direito do Trabalho. 28. ed. São Paulo: Atlas, 2012.

MATTOSO, Jorge. Emprego e concorrência desregulada: incertezas e desafios. In: OLIVEIRA, C. E.; MATTOSO, J. E. L. (Orgs.). Crise e trabalho no Brasil: Modernidade ou volta ao passado? São Paulo: Scritta, 1996.

MINISTÉRIO PÚBLICO DO TRABALHO EM MINAS GERAIS. Terceirização versus proteção constitucional. Disponível em: <http://www.prt3.mpt.mp.br/informe-se/noticias-do-mptmg/254-terceirizacao-versus-protecao-constitucional>. Acesso em: 16 ago. 2016.

MORAES, Alexandre de. Direito constitucional. 25. ed. São Paulo: Atlas, 2010.

ONU. Declaração Universal dos Direitos Humanos. 1948. Disponível em: <http://unesdoc.unesco.org/images/0013/001394/139423por.pdf>. Acesso em: 16 ago. 2016.

PANCOTTI, José Antônio. Aspectos jurídicos da dispensa coletiva no Brasil. Revista do Tribunal Regional do Trabalho da $15^{\text {a }}$ Região, Campinas, n. 35, p. 39-67, 2009.

PAULA, Carlos Alberto Reis de. Dispensa coletiva e negociação. Rev. TST, Brasília, v. 77, n. 2 , abr./jun. 2011. Disponível em:

<http://aplicacao.tst.jus.br/dspace/bitstream/handle/1939/25343/016_paula.pdf?sequence=4> Acesso em: 16 ago. 2016.

PÔRTO, Marcos da Silva. A terminação do contrato de emprego. In: GIORDANI, Francisco Alberto da Motta Peixoto; MARTINS, Melchíades Rodrigues; VIDOTTI, Tarcio José. (Coords.).

Fundamentos dos direito do trabalho: Estudos em homenagem ao Ministro Milton de Moura França.São Paulo: LTr, 2000.

RIFKIN, Jeremy. O fim dos empregos: o declínio inevitável dos níveis dos empregos e a redução da força global de trabalho. São Paulo: Makron Books, 1995.

ROCHA, Cláudio Jannotti da. Reflexões sobre a dispensa coletiva brasileira. Rev. Trib. Reg.

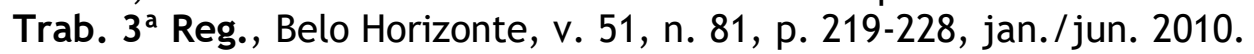

RUBIO, David Sánchez. Crítica a una cultura estática y anestesiada de derechos humanos. Por una recuperación de las dimensiones constituyentes de la lucha por los derechos. Derechos y libertades, Madri, n. 33, época II, p. 99-134, jun. 2015. 


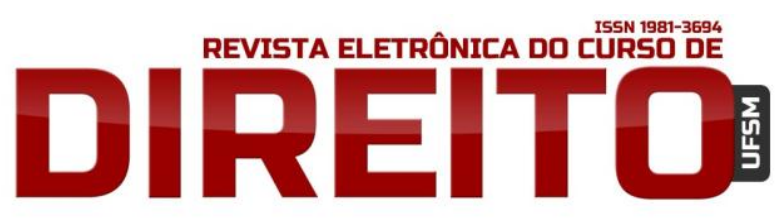

A (DES)NECESSIDADE DE REGULAMENTAÇ̃̃O DA DISPENSA COLETIVA NO BRASIL: UMA ANÁLISE SOB A ÓTICA DO VALOR SOCIAL DO TRABALHO E DA DIGNIDADE DA PESSOA HUMANA

SANTOS, Enoque Ribeiro dos. Fundamentos do Direito Coletivo do Trabalho nos Estados Unidos da América, na União Europeia, no Mercosul e a Experiência Brasileira. Rio de Janeiro:Lumen Juris, 2006.

SILVA, Antônio Álvares da. Questões polêmicas de direto do trabalho: a Convenção 158 da OIT e a garantia no emprego; Juizado Especial de causas trabalhistas. São Paulo: LTr, 1996. v. 8.

SILVA, José Afonso da. Curso de direito constitucional positivo. 35. ed. São Paulo: Malheiros, 2011.

SINGER, Paul. Desenvolvimento e crise. São Paulo: DIFEL, 1968.

SOUTO MAIOR, Jorge Luiz. O direito do trabalho como instrumento de justiça social. São Paulo: LTr, 2000.

SOUTO MAIOR, Jorge Luiz. PDV: o “neoliberalismo" extemporâneo de Zago e a responsabilidade do Conselho. Disponível em: <http://cartamaior.com.br/?/Editoria/Educacao/PDV-oneoliberalismo-extemporaneo-de-Zago-e-a-responsabilidade-do-Conselho/13/31732\& page=1>. Acesso em: 16 ago. 2016.

TAVARES, André Ramos. Direito Constitucional Econômico. 2. ed. São Paulo: Editora Método. 2006.

TEODORO, Maria Cecília Máximo; SILVA, Aarão Miranda da. A imprescindibilidade da negociação coletiva nas demissões em massa e a limitação de conteúdo constitucionalmente imposta. Âmbito Jurídico, Rio Grande, XII, n. 64, maio 2009. Disponível em: <http://www.ambitojuridico.com.br/site/index.php?n_link=revista_artigos_leitura\&artigo_id=6082>. Acesso em: 16 ago. 2016.

VIALÔGO, Tales Manoel Lima; NEGREIROS, Guilherme Enei Vidal de. A demissão coletiva no direito brasileiro. Revista JurisFIB, Bauru, v. III, a. III, dez. 2012. Disponível em: <http://www.revistajurisfib.com.br/artigos/1359118566.pdf>. Acesso em: 16 ago. 2016.

Recebido em: 29/06/2016 / Revisões requeridas em: 06/02/2017 / Aprovado em: 04/03/2017 